\title{
Marine megafauna interactions with small-scale fisheries in the southwestern Indian Ocean: a review of status and challenges for research and management
}

\author{
Andrew J. Temple $(\mathbb{D} \cdot$ Jeremy J. Kiszka $\odot$ - Selina M. Stead • Nina Wambiji 1 • \\ Atanásio Brito $\cdot$ Christopher N. S. Poonian • Omar A. Amir • Narriman Jiddawi • \\ Sean T. Fennessy $\cdot$ Sergi Pérez-Jorge $10 \cdot$ Per Berggren
}

Received: 23 December 2016/ Accepted: 3 August 2017/Published online: 18 August 2017

(C) The Author(s) 2017. This article is an open access publication

\begin{abstract}
In developing regions, coastal communities are particularly dependent on small-scale fisheries for food security and income. However, information on the scale and impacts of small-scale fisheries on coastal marine ecosystems are frequently lacking. Large marine vertebrates (marine mammals, sea turtles and chondrichthyans) are often among the first species to experience declines due to fisheries. This paper reviews the interactions between small-scale fisheries and vulnerable marine megafauna in the southwestern Indian Ocean. We highlight an urgent
\end{abstract}

Electronic supplementary material The online version of this article (doi:10.1007/s11160-017-9494-x) contains supplementary material, which is available to authorized users.

\section{A. J. Temple $(\bowtie) \cdot$ S. M. Stead · P. Berggren}

School of Marine Science and Technology, Newcastle

University, Newcastle-upon-Tyne, UK

e-mail: andrew.temple@ncl.ac.uk

\section{J. J. Kiszka}

Department of Biological Sciences, Florida International University, Miami, FL, USA

\section{N. Wambiji}

Kenya Marine and Fisheries Research Institute, Mombasa, Kenya

\section{A. Brito}

Fisheries Research Institute, Maputo, Mozambique

C. N. S. Poonian

Community Centred Conservation (C3), London, UK need for proper documentation, monitoring and assessment at the regional level of small-scale fisheries and the megafauna affected by them to inform evidence-based fisheries management. Catch and landings data are generally of poor quality and resolution with compositional data, where available, mostly anecdotal or heavily biased towards easily identifiable species. There is also limited understanding of fisheries effort, most of which relies on metrics unsuitable for proper assessment. Management strategies (where they exist) are often created without strong evidence bases or understanding of the reliance of fishers on resources. Consequently, it is not possible to effectively assess the current status and ensure the sustainability of these species groups; with indications

\author{
O. A. Amir \\ Ministry of Agriculture, Natural Resources, Livestock and \\ Fisheries, Zanzibar, United Republic of Tanzania \\ N. Jiddawi \\ Institute of Marine Sciences, University of Dar es Salaam, \\ Zanzibar, United Republic of Tanzania \\ S. T. Fennessy \\ Oceanographic Research Institute, Durban, South Africa \\ S. Pérez-Jorge \\ Watamu Marine Association, Watamu, Kenya
}


of overexploitation in several areas. To address these issues, a regionally collaborative approach between government and non-governmental organisations, independent researchers and institutions, and smallscale fisheries stakeholders is required. In combination with good governance practices, appropriate and effective, evidence-based management can be formulated to sustain these resources, the marine ecosystems they are intrinsically linked to and the livelihoods of coastal communities that are tied to them.

Keywords Bycatch - Conservation - Elasmobranch Livelihoods · Mammal · Turtle

\section{Introduction}

Large marine vertebrates such as marine mammals, sea turtles and chondrichthyans are highly vulnerable to non-natural mortalities resulting from anthropogenic activities, especially fisheries (Lewison et al. 2004; Read et al. 2006; Žydelis et al. 2009). This is a result of the mainly k-selected life history displayed by these species groups: comparatively long-life, high natural survivorship, slow growth, late maturity and low fecundity. Chondrichthyans, comprising the chimeras and elasmobranchs (sharks and batoids), marine mammals (specifically cetaceans and sirenians) and sea turtles represent some of the most threatened animal groups (Online Resource 1). Using IUCN Red List criteria, both marine mammals and sea turtles represent a relatively small number of species (92 and 7, respectively) with high levels of vulnerability. In contrast, chondrichthyans combine large numbers of species (546 batoids, 475 sharks and 46 chimeras) and high levels of vulnerability with the highest proportions of Data Deficient and lowest of Least Concern status of any vertebrate class (Dulvy et al. 2014; Hoffmann et al. 2010; IUCN 2016). These species provide vital marine ecosystem services at various levels. As apex and meso-predators across a number of food webs they affect community structure and dynamics (Heithaus et al. 2008; Kiszka et al. 2015), and as grazers impact seagrass systems and nutrient cycling (Aragones et al. 2006; Burkholder et al. 2013; Preen 1995). Therefore, the loss of vulnerable marine megafauna has potential consequences for ecosystem structure and function, with implications and impacts across multiple spatiotemporal scales.

The complex interrelationships between marine megafauna and human impacts on the marine ecosystem make simultaneously managing the use of marine resources and protection of these species especially challenging. Fisheries are widely considered the greatest threat to vulnerable marine megafauna (Dulvy et al. 2014; Lewison et al. 2004; Read et al. 2006; Wallace et al. 2010). Many are non-target species, widely perceived to be of low value and are often viewed as a nuisance by fishermen, especially in industrial fisheries. In contract, others, mainly elasmobranchs, are targeted in a range of coastal and oceanic fisheries, particularly for their fins and other products including meat and gill plates (Couturier et al. 2012; Musick 2005). For many fisheries, particularly small-scale fisheries in developing nations, vulnerable marine megafauna species may constitute both target and non-target catch. Indeed, their categorisation as target or by-catch species may vary on a fisher-by-fisher and trip-by-trip basis. As such we herein refer to their presence in the fisheries simply as 'catch'.

The multi-gear nature of many fisheries, the perceptions of many vulnerable marine megafauna as either a nuisance or of low value, together with the illegality of catching certain species and the sometimes-secretive nature of fishermen mean that catch is largely under-reported and data are sparse in many regions, making accurate estimation of global catch exceedingly difficult. However, available estimates indicate that catches are likely unsustainable, with an estimated 0.53-0.82 million marine mammals, 0.85-8.5 million sea turtles and 63-273 million sharks caught worldwide annually (Read et al. 2006; Wallace et al. 2010; Worm et al. 2013). Gillnet and line fisheries account for the majority of marine mammal, elasmobranch and sea turtle catch (Lewison et al. 2004; Read et al. 2006). These fishing methods are relatively inexpensive, simple and effective with widespread usability.

While vulnerable marine megafauna interactions with industrial and commercial fisheries have received some attention, less is known of the magnitude and mechanisms of interaction with small-scale fisheries, herein defined as those fisheries operating either for subsistence or for income generation (artisanal) but not as part of a commercial company, particularly in 
the developing regions. Globally, small-scale fisheries include some 50 million fishers (FAO 2016c), more than $95 \%$ of fishers worldwide (Pauly 2006). They are especially prevalent in the developing regions of South and Central America, Africa and the IndoPacific. Given their prevalence and widespread occurrence the environmental impacts of small-scale fisheries are likely significant, though they are often overlooked (e.g. Hawkins and Roberts 2004; Moore et al. 2010; Salas et al. 2007). With continued unregulated exploitation, small-scale fisheries can negatively impact the abundance, distribution and species composition of vulnerable taxa (Pinnegar and Engelhard 2008), including vulnerable marine megafauna. Thus, small-scale fisheries may lead to declines of these key species with consequences for the broader food web and ecosystem, including other species that are critical to local livelihoods.

In developing regions small-scale fisheries are of considerable socio-economic importance, particularly in rural areas where they are important contributors to the local economy (Béné 2006; Pauly 2006) and to food security. In these regions elasmobranchs, sea turtles and marine mammals were historically important sources of human sustenance and remain so in many areas (Robards and Reeves 2011; Vannuccini 1999). Elasmobranchs are most important in this respect, but hunts still exist for both sea turtles and marine mammals, often in spite of national or international laws and regulations banning these practices (Cerchio et al. 2009; Hart et al. 2013; Humber et al. 2014; Kasuya 2007; Riedmiller 2013). Vulnerable marine megafauna are an important source of income, both in fisheries and increasingly from ecotourism activities (Cisneros-Montemayor et al. 2013; O'Connor et al. 2009). However, there is a lack of information regarding the non-monetary, including cultural, value of vulnerable marine megafauna to fishers, which has implications both for decisionmaking regarding catch and conservation of these species and for the full understanding of their societal value.

Our aim in this paper is to review existing knowledge and status regarding vulnerable marine megafauna interactions with marine small-scale fisheries in the southwestern Indian Ocean (SWIO) region. Data were gathered from a range of sources including, but not limited to, information requests from relevant government departments in SWIO nations, scientific and non-governmental organisations (NGO) publications and reports, international and national annual reports and databases. We discuss the likely implications of the current situation, highlighting vital knowledge gaps that need to be addressed and challenges for future research and management across the region.

\section{Southwestern Indian Ocean profile}

The SWIO, as considered in this review, consists of 8 countries (and their Economic Exclusive Zones) with broadly comparable fisheries: Comoros, Kenya, Madagascar, Mauritius, Mayotte and La Réunion (France), Mozambique, the Seychelles and Tanzania (including Zanzibar) (Fig. 1, Online Resource 2). The region's human population is projected to more than double from 155 million to 357.3 million by 2050 (WB 2016b), with coastal cities and island nations experiencing particularly high rates of population increase (Online Resource 2). Food security and income generation are therefore major policy drivers requiring sustainable solutions built on sound management practices. Coastal communities have traditionally relied on marine fishes (including elasmobranchs) as their main sources of protein, with some also making use of marine mammals and sea turtles for sustenance or as bait (Church and Palin 2003; Humber et al. 2011; Razafindrakoto et al. 2008). Marine fisheries (including mariculture) account for 0.5-30\% of Gross Domestic Product (GDP), with island nations particularly reliant (Online Resource 2). However, other marine income-generating activities also contribute to local economies, particularly marine-tourism activities, worth around \$3.95billion, including recreational fishing, whale and dolphinwatching and dive tourism (Amir and Jiddawi 2001; Divetime 2016; Gallagher and Hammerschlag 2011; Obura 2017; O'Connor et al. 2009; O’Malley et al. 2013; Pérez-Jorge et al. 2016). Some countries in the SWIO, like the Seychelles, are focusing on expanding their other food security sectors (e.g. mariculture) to reduce reliance on vulnerable fisheries especially in the face of climate change (Stead et al. 2015).

The SWIO (part of FAO Fishing Area 51) has among the highest marine species richness worldwide (Tittensor et al. 2010; Worm and Branch 2012). This diversity is threatened by increasing anthropogenic 


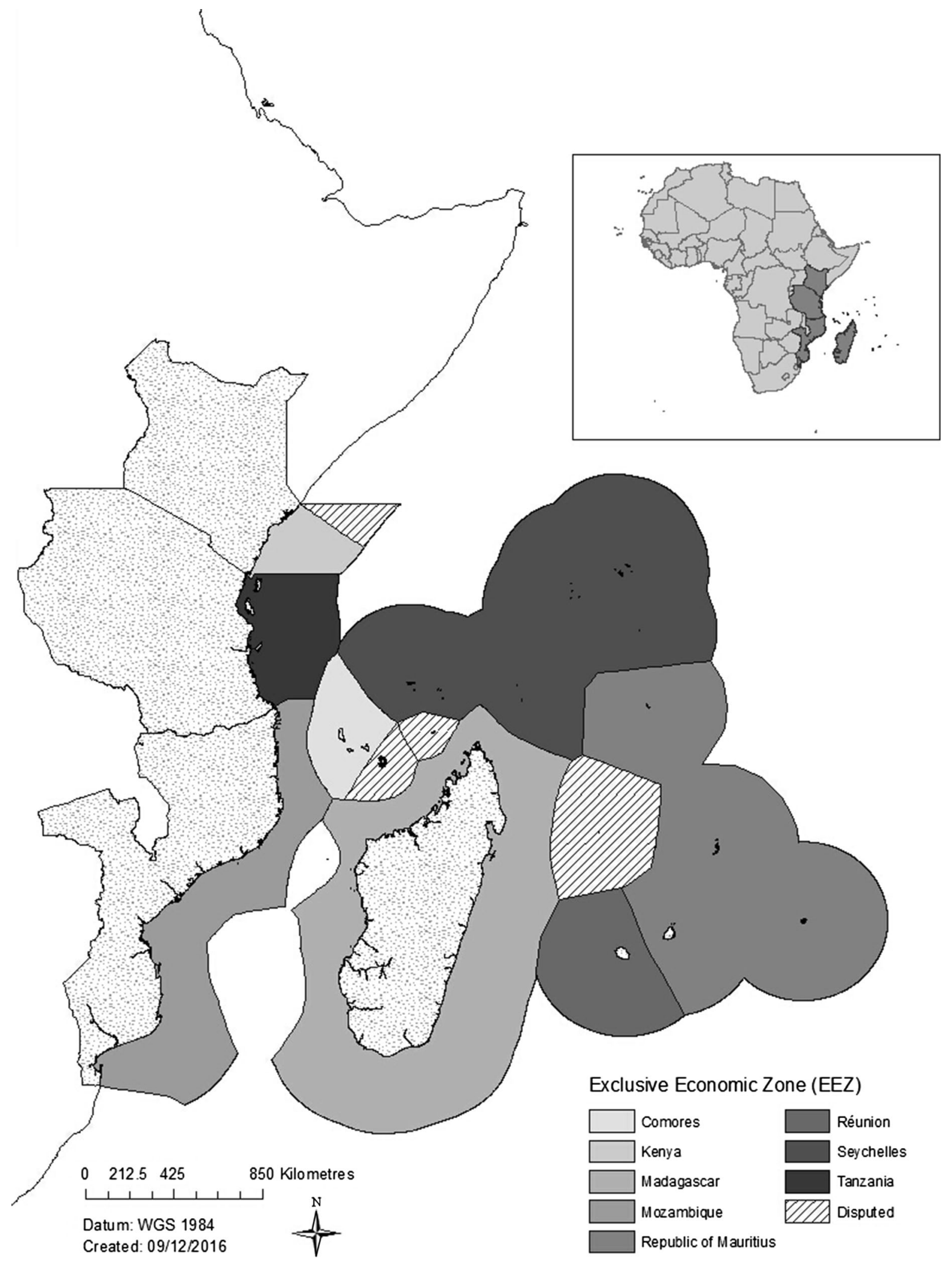


4Fig. 1 The southwestern Indian Ocean: Comoros, Kenya, Madagascar, Mauritius, Mayotte and La Réunion (France), Mozambique, Seychelles and Tanzania (mainland and Zanzibar). Sources: ESRI (2014), VLIZ (2014)

pressure, especially from fisheries, and limited management effectiveness where it exists (Mora et al. 2009; Worm et al. 2013). The area contains a high diversity of vulnerable marine megafauna species but there is large uncertainty regarding status, catch and trends of many of these at both a global (Online Resource 1) and regional scale (Kiszka 2015; Kiszka and van der Elst 2015). These uncertainties, coupled with the high proportion of vulnerability and mostly decreasing trends (Online Resource 1) in assessed species is a major concern.

The risk to vulnerable marine megafauna species in the SWIO is further exacerbated by the continued expansion of the dominant yet largely poorly documented and unregulated small-scale fisheries. Smallscale fisheries officially account for 75-85\% of marine landings across SWIO nations (Pauly and Zeller 2015), with annual landings reportedly 345,000-390,000 mt as of 2014 (FAO 2016b). However, independent estimates suggest gross under-reporting of landings and effort, with total SWIO landings estimated to average $165 \%$ greater than reported figures for 1950-2010 (Fig. 2; Pauly and Zeller 2015). Although these are retrospective estimates, they provide an improved assessment of the landings magnitude and serve as a useful reference point.

Small-scale fisheries of the southwestern Indian Ocean: main features and data quality

Currently the SWIO small-scale fisheries employ more than 495,000 fishers operating 150,000 assorted vessels across the SWIO (Table 1), with the largest fleets in Madagascar and Mozambique. However, this does not account for many of the unlicensed smallscale fisheries fishers, which are of substantial number (Teh and Sumaila 2013). Unlicensed and open-access fishing is a major issue for SWIO small-scale fisheries, with direct implications for the assessment of catch and socio-economic value of these fisheries and so inhibiting effective stock management. Additionally, small-scale fisheries support various other livelihoods, including: auctioneers, fish mongers, middlemen, gear repairers and fish fryers among others.
In terms of fisher participation the regional fisheries are dominated by handlines (Table 1), with simplicity, ease of use and affordability as likely drivers. However, more advanced gears are increasingly used. Specifically, fisheries in Kenya, Madagascar, Mozambique, the Seychelles and Tanzania (including Zanzibar) are using longline (demersal and pelagic) and gillnet (drift and bottom set) gears (Table 1), mostly targeting sharks and pelagic fishes.

Assessing general landings trends in the SWIO small-scale fisheries is challenging. Whilst long-term data sets are available through the FAO (Fig. 2) and national reports, the validity and quality of these are questionable given the lack of standardised and systematically collected historical data, particularly regarding effort, and unlicensed fishing. However, if we consider only data from recent years (Fig. 3; KMALF 2015; MFR 2012; SFA 2015; L'Institut Français de Recherche pour l'Exploitation de la Mer unpublished data; Tanzania Ministry of Livestock and Fisheries Development unpublished data; Seychelles Fishing Authority unpublished data) landings appear relatively stable in most nations, with a marked overall regional increase (Fig. 2). Decreasing trends are seen in the official data from Mauritius and La Réunion, reflecting the declining effort (vessel numbers and fisher days respectively) in these fisheries (MFR 2010; L'Institut Français de Recherche pour l'Exploitation de la Mer unpublished data). Conversely a rapid increase in official landings has been observed for Mozambique, likely driven by improvements in both monitoring programmes and proper extrapolation of data to the national level (Doherty et al. 2015).

Compounding the issues regarding monitoring efficacy and accuracy is the widespread commonality of national and international migrant fisheries in the region (WIOMSA 2011). These catches may be taken in one nation and declared in another, declared in both or in neither. Undeclared transhipment of catches to neighbouring markets is also common. For example catches in Zanzibar are often landed, compiled and shipped directly to markets in mainland Tanzania or southern Kenya, often following a seasonal pattern (Fowler et al. 2005; Wanyonyi et al. 2016; A. Temple personal observation). These may have significant impact on landings data and could have consequences for stock management.

The biggest stumbling block in the monitoring and management of SWIO small-scale fisheries is the lack 
Fig. 2 Official and estimated landings data for SWIO nation's fisheries between 1950 and 2013. Data sources: FAO (2016b), Pauly and Zeller (2015)

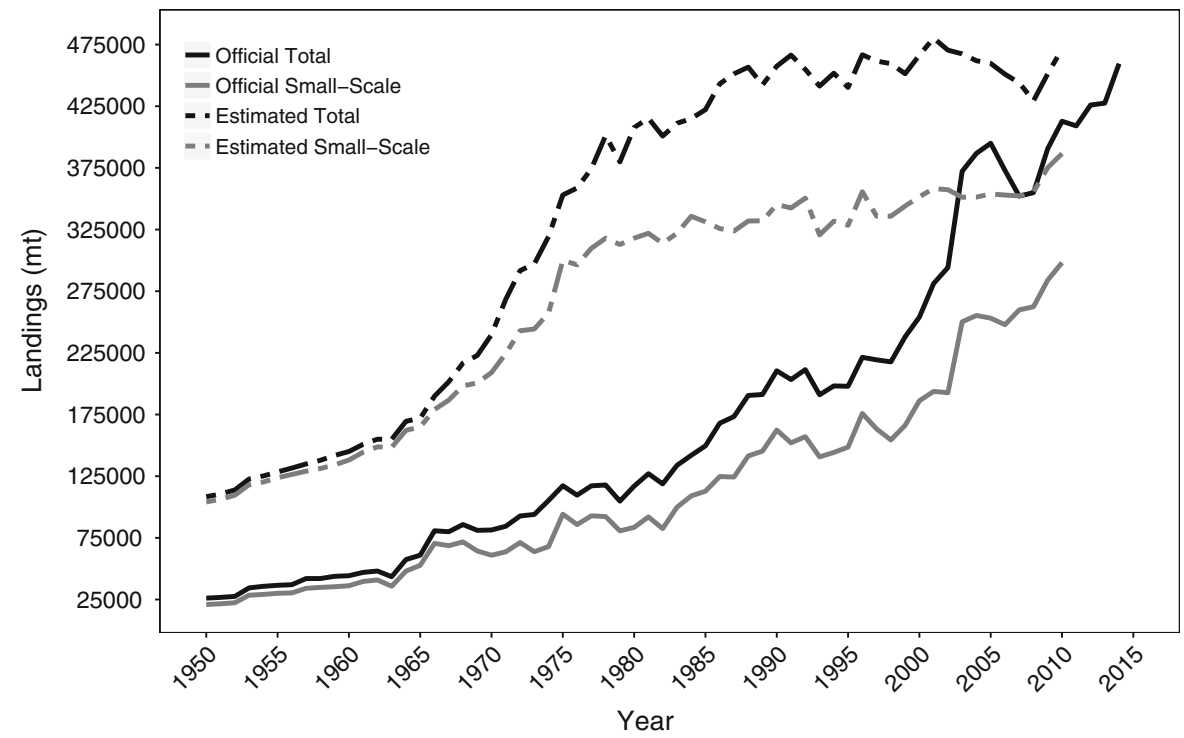

of standardised data and the relatively poor resolution of landings and effort data available. The variability in basic recording metrics (Online Resource 3) hinders the comparability and summation of data at the regional scale, with only simple measures feasible for use i.e. effort can only be regionally derived through vessel count data. Measures and definitions of gear type, effort metrics and vessel types differ between countries and even within countries between years, whilst the breakdown of data by geographic region, gear and vessel types is often inconsistent over time. Data reports have variable formats and contents, and are often unclear as to whether data presented are that observed or whether they have been extrapolated to country level. Most notably data are inconsistent among reports. For example, there are a number of years (1990, 1993, 1994, 2000 and 2007) where artisanal handline and troll line numbers reported by the Seychelles to the Indian Ocean Tuna Commission (IOTC) are greater than the numbers reported by the Seychelles Fishing Authority for its entire artisanal fleet (IOTC 2016a; SFA 2001-2013). Similarly Kenya reports $165 \mathrm{mt}$ of all elasmobranchs landed from artisanal fisheries in its 2007 statistical bulletin, yet reports $174 \mathrm{mt}$ of sharks alone from the same fishery and year to the IOTC (IOTC 2016a; KMALF 2008). Clearly, these issues must be addressed, both at national and the regional levels, if small-scale fisheries are to be sustainably managed and vital livelihoods protected across coastal areas of the SWIO region.

\section{Marine mammal interaction with small-scale fisheries}

There is limited information available on marine mammal populations and their interaction with the small-scale fisheries of the SWIO (Kiszka 2015; Kiszka et al. 2009), but where data exists there is evidence of both targeted and incidental catch. Catches, mostly incidental, have been documented in the Comoros and Mayotte (Kiszka et al. 2007, 2010; Poonian et al. 2008; Pusineri et al. 2013; Pusineri and Quillard 2008), Zanzibar and Tanzania (Amir 2010; Amir et al. 2002; Muir and Kiszka 2012), Kenya (Kiszka 2012), Madagascar (Cerchio et al. 2009; Razafindrakoto et al. 2004, 2008), Mozambique (Guissamulo and Cockcroft 1997; Kiszka 2012) and La Réunion (Kiszka et al. 2009). To date no marine mammal catch has been reported in Mauritius or the Seychelles (Kiszka et al. 2009). Published studies identify coastal gillnet fisheries (both drift and set nets) as the main threat to marine mammals across the region, although interactions have also been documented in longline fisheries (Kiszka et al. 2009, 2010).

Understanding the true impacts of these catches requires data on capture rates and abundance estimates for any given population investigated. To date population abundances have only been estimated for two cetacean species in restricted areas of the SWIO: Indian Ocean humpback (Sousa plumbea) and IndoPacific bottlenose dolphins (Tursiops aduncus) in the 
Table 1 Marine small-scale fishery vessel, fisher and gear data for South Western Indian Ocean nations. Data Source: Andriantsoa and Randriamiarisoa (2013), Chacate and Mutombene (2015), Chavance et al. (2014), ESAP (2005), de Graaf and Garibaldi (2014), Herfaut (2006), KMALF (2014a, b, 2015), MFR (2010), Ndegwa (2015), SFA (2015), Soilihi (2014), ZMLF (2010), Albion Fisheries Research Centre unpublished data; L'Institut Français de Recherche pour l'Exploitation de la Mer unpublished data, Instituto Nacional de Investigação Pesqueira personal communication)

\begin{tabular}{|c|c|c|c|c|c|c|c|}
\hline \multirow[t]{2}{*}{ Country } & \multirow{2}{*}{$\begin{array}{l}\text { Vessels } \\
\text { (year) }\end{array}$} & \multirow{2}{*}{$\begin{array}{l}\text { Fishers } \\
\text { (year) }\end{array}$} & \multicolumn{5}{|c|}{ Gear prevalence } \\
\hline & & & $\begin{array}{l}\text { Measure } \\
\text { (year) }\end{array}$ & Handline & Longline & Gillnet & $\begin{array}{l}\text { Other/ } \\
\text { unknown (\%) }\end{array}$ \\
\hline Comoros & 3601 (2012) & Unknown & $\begin{array}{l}\text { Vessels } \\
\text { (2012) }\end{array}$ & $\begin{array}{l}23.25 \% \text { static } \\
23.12 \% \text { trolled }\end{array}$ & - & $3.11 \%$ drift & 50.51 \\
\hline Kenya & $\begin{array}{l}2913 / 3500 \\
(2013 / 2014)\end{array}$ & $\begin{array}{l}12,915 \\
(2013)\end{array}$ & $\begin{array}{l}\text { Gears } \\
\quad(2014)\end{array}$ & $\begin{array}{l}20.35 \% \text { static } \\
2.81 \% \text { trolled }\end{array}$ & $\begin{array}{l}28.48 \% \\
\text { (strings) }\end{array}$ & $\begin{array}{l}\text { 9.44\% mono- } \\
\quad \text { filament } \\
8.41 \% \text { set } \\
5.14 \% \text { drift } \\
1.07 \% \text { active }\end{array}$ & 24.31 \\
\hline Madagascar & $\begin{array}{l}78,787^{\mathrm{a}} \\
(2012)\end{array}$ & $\begin{array}{l}119,334 \\
(2011)\end{array}$ & $\begin{array}{l}\text { Gears } \\
\text { (2012) }\end{array}$ & $67.69 \%$ "lines"b & & $27.23 \%$ & 5.08 \\
\hline Mauritius & $\begin{array}{l}2476 \\
(2010)\end{array}$ & $\begin{array}{l}2,038^{\mathrm{c}} \\
(2014)\end{array}$ & $\begin{array}{l}\text { Fishers } \\
\quad(2014)\end{array}$ & $\begin{array}{l}66.00 \% \text { line\&trap } \\
21.05 \% \text { line/ } \\
\text { harpoon/foot }^{\mathrm{d}}\end{array}$ & - & $\begin{array}{l}5.89 \% \text { "large } \\
\text { net" } \\
0.49 \% \text { "gillnet" }\end{array}$ & 6.58 \\
\hline Mayotte & $\begin{array}{l}1132 \\
(2014)\end{array}$ & $\begin{array}{l}4800 \\
\quad(2003)\end{array}$ & $\begin{array}{l}\text { Landings } \\
\text { (2005) }\end{array}$ & $\begin{array}{l}57 \% \text { static } \\
32 \% \text { trolled }\end{array}$ & - & $\begin{array}{l}\sim 10 \% \\
\text { encircling }\end{array}$ & $\sim 1$ \\
\hline Mozambique & $\begin{array}{l}45,805^{\mathrm{d}} \\
(2013)\end{array}$ & $\begin{array}{l}285,000 \\
(2012)\end{array}$ & $\begin{array}{l}\text { Gears } \\
\text { (2012) }\end{array}$ & $25.75 \%$ & $2.00 \%$ & $37.57 \%$ & 34.68 \\
\hline La Réunion & $\begin{array}{l}172 \\
(2014)\end{array}$ & $\begin{array}{l}340 \\
(2014)\end{array}$ & $\begin{array}{l}\text { Vessels } \\
\quad(2014)\end{array}$ & $88.37 \%$ & $8.72 \%$ & - & 2.91 \\
\hline Seychelles & $\begin{array}{l}424^{\mathrm{e}} \\
(2014)\end{array}$ & Unknown & $\begin{array}{l}\text { Landings } \\
\text { (2014) }\end{array}$ & $\begin{array}{l}56.28 \% \text { line } \\
3.71 \% \text { line\&trap }\end{array}$ & - & $\begin{array}{l}20.86 \% \\
\text { encircling }\end{array}$ & 19.15 \\
\hline $\begin{array}{l}\text { Tanzania } \\
\text { (mainland) }\end{array}$ & $\begin{array}{l}7664 \\
(2009-2014)\end{array}$ & $\begin{array}{l}36,321 \\
(2014)\end{array}$ & $\begin{array}{l}\text { Gears } \\
\quad(2014)\end{array}$ & $25.24 \%$ & $17.07 \%$ & $\begin{array}{l}36.06 \% \text { set } \\
6.75 \% \text { drift }\end{array}$ & 14.88 \\
\hline Zanzibar & $\begin{array}{l}8,639^{f} \\
(2010)\end{array}$ & $\begin{array}{l}34,571 \\
(2010)\end{array}$ & $\begin{array}{l}\text { Gears } \\
\quad(2010)\end{array}$ & $44.11 \%$ & $1.76 \%$ & $\begin{array}{l}13.46 \% \text { drift } \\
4.07 \% \text { set }\end{array}$ & 36.60 \\
\hline Total & 151,613 & 495,319 & & & & & \\
\hline
\end{tabular}

${ }^{a}$ Interim results for 9 regions, of 22

b not broken down

c registered fishers

d vessel licenses not vessel numbers

e average vessels active/month

f 9609 vessels predicted by 2015

Menai Bay Conservation Area off the south coast south of Unguja Island, Zanzibar and in the KisiteMpunguti Marine Protected Area (MPA), Kenya (Meyler et al. 2012; Pérez-Jorge et al. 2015, 2016; Stensland et al. 2006); and T. aduncus off the southwest of Mauritius (Webster et al. 2014), around Mayotte (Pusineri et al. 2014) and La Réunion (Dulau et al. 2017). Capture rate estimates are only available for Zanzibar, with these showing unsustainable levels of fisheries mortality for both species (Amir 2010; Amir et al. 2002). Numbers of the dugong (Dugon dugon) have significantly reduced across the SWIO region with only relict populations remaining in the region, the largest of which exists in Mozambique 

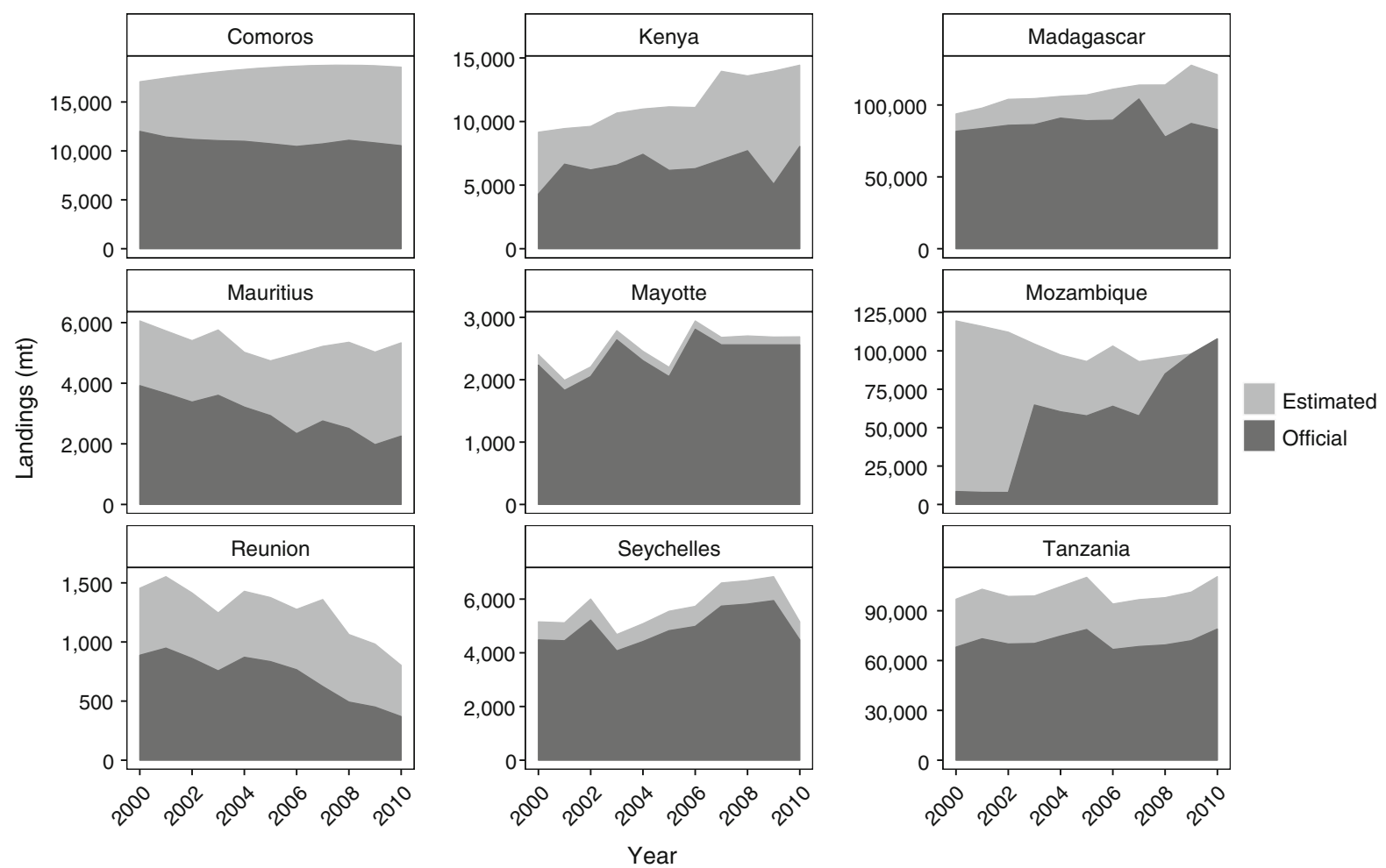

Fig. 3 SWIO small-scale fisheries landings 2000-2010. Note different scales on the y-axes. Data sources Pauly and Zeller (2015)

(WWF-EAME 2004). Evidence of ongoing catches has led to serious concern for the future viability of this species (Kiszka 2015; Kiszka et al. 2007). Of further concern is the on-going illegal hunt for marine mammals in Madagascar (Cerchio et al. 2009; Razafindrakoto et al. 2008) and Tanzania (Riedmiller 2013), possibly in Mayotte (Kiszka et al. 2009) and likely other parts of the region.

Currently there are no annual statistics relating to the catch or landings of marine mammals in the SWIO region. Minimal attention is given to these species as a component of the fisheries at a national level and there is likely an inherent reluctance to report any such catch given its illegality. Yet, this is hardly a problem restricted to this region, rather it is one at the global level.

\section{Sea turtles interaction with small-scale fisheries}

Five species of sea turtles are known to occur in the SWIO, but green (Chelonia mydas), loggerhead (Caretta caretta) and hawksbill turtles (Eretmochelys imbricata) are the most common and widely distributed in the region (Bourjea 2015). Sea turtles have attracted both long-term and intensive studies in the SWIO relative to other vulnerable marine megafauna species. Nevertheless, there are still major data gaps e.g. unreliable nesting data and a lack of species abundance estimates, partially as a result of their highly mobile and complex life history preventing comprehensive population level assessment for most species in the SWIO region (Bourjea 2015). However, qualitative global assessments rank loggerhead, leatherback (Dermochelys coriacea) and olive ridley (Lepidochelys olivacea) as high risk species in the western Indian Ocean, with olive ridley and green considered to face the greatest levels of threat to survival (Wallace et al. 2011, 2013).

Three gear-types have been identified as catching substantial numbers of sea turtle, namely gillnets, prawn/shrimp trawls and longlines (Bourjea et al. 2008; FAO 2010; Wallace et al. 2013). Yet, in most countries of the region, the extent and impact of fisheries on sea turtles is poorly known, except for open ocean fisheries (Bourjea et al. 2014). Both 
incidental and targeted catch of sea turtles appear widespread in small-scale fisheries (for review see Bourjea (2015) and Bourjea et al. (2008)), with the threat posed by gillnet and line gears across the region to sea turtles well established (Bourjea et al. 2008; Kiszka et al. 2010; Poisson and Taquet 2001; Poonian et al. 2008). However, there are no annual statistics of note for sea turtle capture in the SWIO. Kenya is the only reporting nation, for which it has reported $0 \mathrm{mt} /$ year since 1964 (FAO 2016b). Whilst other sources of quantitative data are sparse, and for areas where data exist they are rarely comprehensive, it appears annual regional small-scale fisheries catch is in the order of tens or even hundreds of thousands (Table 2), representing a serious threat to the survival of sea turtles in the SWIO. This is compounded further by alterations and destruction of nesting beaches in some areas, sizeable egg poaching activities and hunting of nesting females, which are common across the region (Bourjea 2015).

\section{Elasmobranch interaction with small-scale fisheries}

In 2014, 34 countries across all fisheries scales reported $105,969 \mathrm{mt}$ of elasmobranch landings originating from the western Indian Ocean region, of which only 17,663 mt were landed by SWIO nations (Fig. 4; FAO 2016b). Of this a disproportionate amount (89.6\%) was accounted for by Tanzania (including Zanzibar) and Madagascar, which together account for $62 \%$ of known SWIO small-scale vessels (Table 1). It is therefore unlikely that the reporting reflects the true proportional contribution of SWIO nations. The regional estimate is likely an underestimate, resulting from under-reporting of landings, illegal fishing and discards, and is consistent with the under-reporting of other landings in the SWIO region (Pauly and Zeller 2015). Despite the high level and year-on-year increase in landings across the SWIO (Fig. 4) little independent research has been undertaken on these fisheries.

There is a notable imbalance ( $>80 \%$ of peerreviewed papers) between studies focussing on elasmobranchs in the industrial and semi-industrial fisheries e.g. (Fennessy 1994; Huang and Liu 2010; Kiszka and van der Elst 2015; Romanov 2002) and the small-scale fisheries (Molina and Cooke 2012). Published information for small-scale fisheries is generally sparsely quantified and limited to target species (e.g. Marshall 1997b; McVean et al. 2006; Schaeffer 2004). Grey literature, in the form of unpublished theses, governmental and consultancy reports, data

Table 2 Existing numerical data for sea turtle catch in the small-scale fisheries of the South Western Indian Ocean. Data Source: Humber et al. (2011), Kiszka (2012), Muir (2005), Muir and Ngatunga (2007), Okemwa et al. (2004), Pusineri and Quillard (2008), Rakotonirina and Cooke (1994)

\begin{tabular}{|c|c|c|c|c|c|}
\hline Country & Scale & Gears & Year & Catch estimate & Method \\
\hline Kenya & $\begin{array}{l}\text { Regional- } \\
\text { Watamu Kiunga }\end{array}$ & Net & Unknown & $\sim 600 /$ year & Catch data \\
\hline \multirow[t]{3}{*}{ Madagascar } & $\begin{array}{l}\text { National-Subset } \\
\text { of Fishers }\end{array}$ & $\begin{array}{l}\text { Terrestrial trap, Harpoon, Diving, Net, } \\
\text { Longline, Poison }\end{array}$ & 1987 & $\begin{array}{l}\text { 11,061/year (17 target } \\
\text { fishers) }\end{array}$ & $\begin{array}{l}\text { Interview } \\
\text { survey }\end{array}$ \\
\hline & & & & $\begin{array}{l}\text { 215/year ( } 16 \\
\text { incidental fishers) }\end{array}$ & \\
\hline & $\begin{array}{l}\text { Regional- } \\
\text { Southwest }\end{array}$ & Net, Line, Spear & $\begin{array}{l}2006 / \\
2007\end{array}$ & $10,000-16,000 /$ year & $\begin{array}{l}\text { Landings } \\
\text { data }\end{array}$ \\
\hline Mauritius & National & $\begin{array}{l}\text { Beach Seine, Bottom-set Gillnet, Line } \\
\text { under FAD, Handline }\end{array}$ & 2010 & 570/year & $\begin{array}{l}\text { Interview } \\
\text { Survey }\end{array}$ \\
\hline Mayotte & National & All & 2007 & 111-256/year & $\begin{array}{l}\text { Interview } \\
\text { Survey }\end{array}$ \\
\hline \multirow[t]{2}{*}{$\begin{array}{l}\text { Tanzania } \\
\text { Mainland }\end{array}$} & $\begin{array}{l}\text { Regional-Mafia } \\
\text { Island }\end{array}$ & Gillnet & Unknown & 1000-2000/year & Unknown \\
\hline & $\begin{array}{l}\text { National- } \\
\text { Incidental Only }\end{array}$ & & Unknown & 617-6170/year & $\begin{array}{l}\text { Interview } \\
\text { survey }\end{array}$ \\
\hline
\end{tabular}


Fig. 4 Total landings data for elasmobranchs caught by South Western Indian Ocean nations 1970-2013.

Zanzibar and Tanzania are reported separately after 2000. Data Source: FAO (2016b)

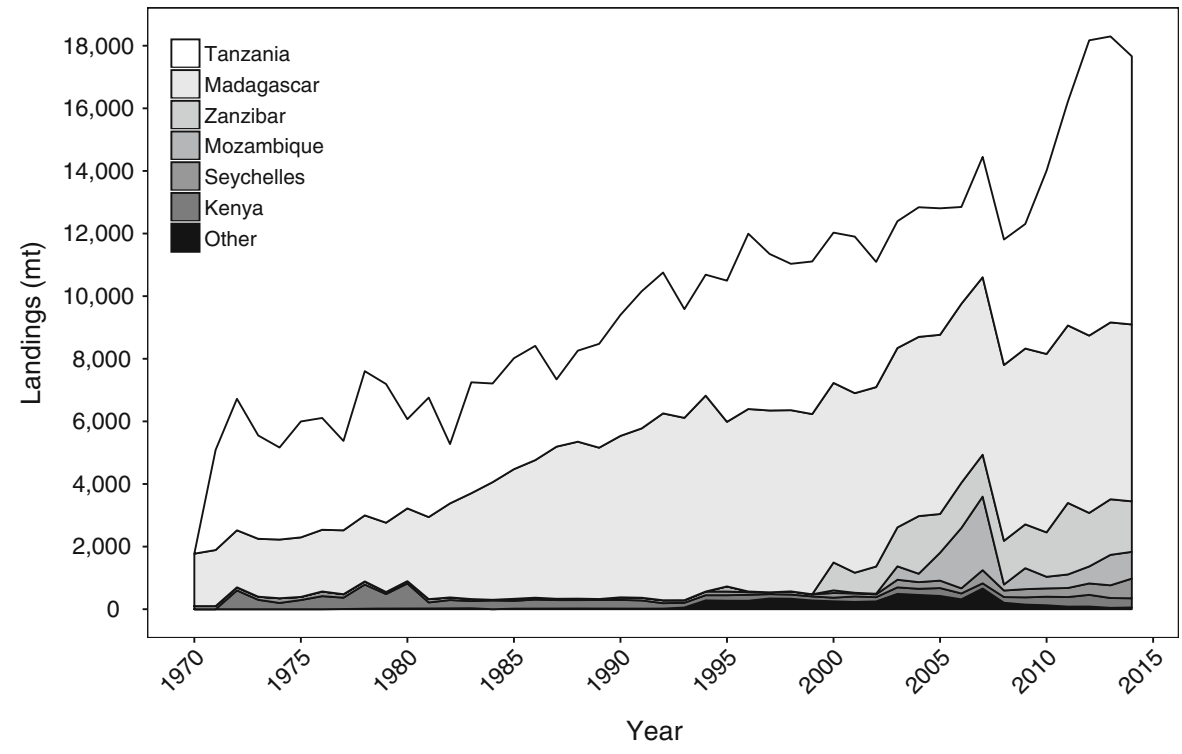

collected by NGO's and other such works exist. However, much of this information is not easily accessible and in some cases remains confidential. This highlights a need to better the flow of information to responsible organisations and into the public domain.

A variety of species are regularly taken in the region's fisheries, with the most commonly reported being blue (Prionace glauca) and silky (Carcharhinus falciformis) sharks from the industrial longline and purse seine fisheries (Smale 2008). Concurrently, a number of species are known to appear in the region's small-scale fisheries (Table 3). The species listed are influenced by ease of identification and observation bias. As such they are unlikely to accurately reflect fisheries composition but do provide evidence for a level of regional species homogeneity. Most elasmobranch landings in the SWIO region are not identified beyond basic taxonomic level and are simply grouped as "sharks and/or rays" (FAO 2016b). Thus, the data cannot support effective stock management, at either local or regional levels. This is a major constraint to decision-making on fisheries management measures as there is no reliable data for population dynamics, given that that small-scale fishers are reporting significant declines in elasmobranch abundance and catch this demonstrates a clear information gap (Kiszka and van der Elst 2015). Specific data is required to properly document both which species, and in what volume, elasmobranchs are interacting with
SWIO small-scale fisheries. Below, current understanding of elasmobranch catch and landings in SWIO small-scale fisheries is summarised by country:

\section{Comoros}

Since first being reported in 1994, elasmobranch landings in the Comoros have dwindled from 230 to $19 \mathrm{mt}$ by 2013 (FAO 2016b), despite the apparent increases in fishing effort (IOTC 2016a; Soilihi 2014). Import of dried shark meat from Madagascar (Cooke 1997) is one possible driver, with Comorian fisheries known to be unable to meet the domestic demand for dried fish products (WB 2016a). Alternatively, these declines may reflect stock collapses. Blue shark is a major constituent, accounting for $26 \%$ of the $19.97 \mathrm{mt}$ landings in 2012 (Soilihi 2014). Other commonly reported catch includes a variety of oceanic and coastal species; primarily oceanic whitetip (Carcharhinus longimanus), silky, grey reef ( $C$. amblyrhynchos) and hammerhead (Sphyrna spp.) sharks (Maoulida et al. 2009).

Based on reported landings and gear composition from IOTC National Reports (Soilihi 2014), effective catch per unit effort (CPUE) for sharks is much higher in both static $(775 \mathrm{~kg} / \mathrm{vessel} / \mathrm{year})$ and trolled $(830 \mathrm{~kg} /$ vessel/year) handlines than in net fisheries $(2.20 \mathrm{~kg} /$ vessel/year). Indeed, handlines account for nearly $96 \%$ of the reported blue shark landings. Given the seemingly greater CPUE for sharks in the handline 


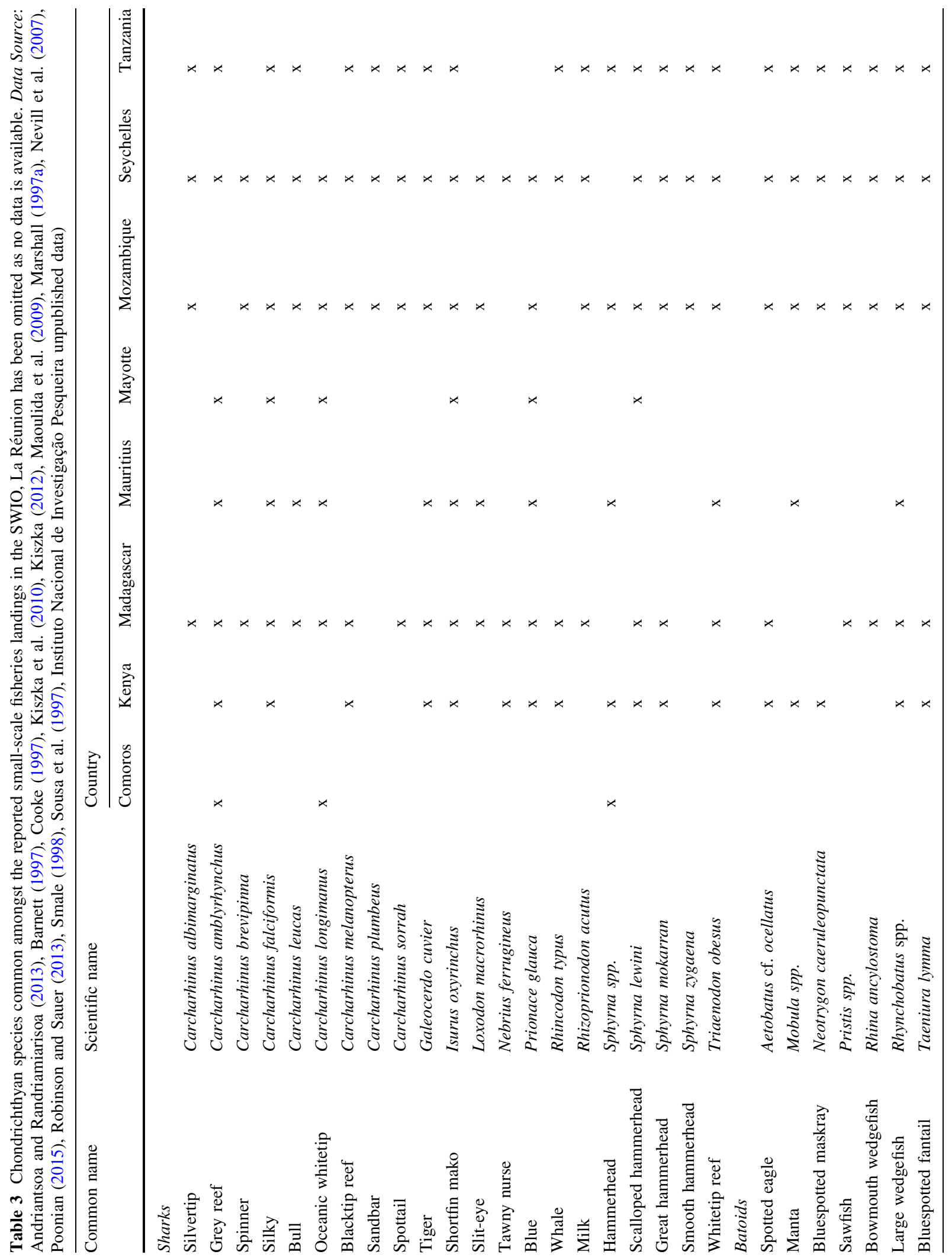


fisheries specific scrutiny should be placed on these in any future assessments. Conversely, the lack of reporting of batoid catches and/or landings combined with their known susceptibility to net gears means the potential contribution of these gears to elasmobranch catches should not be overlooked.

\section{Kenya}

Elasmobranch landings have fluctuated in recent years, dipping as low as $165 \mathrm{mt}$ in 2007, peaking at $373 \mathrm{mt}$ in 2012 and reported at $293 \mathrm{mt}$ in 2014 (Ndegwa 2015). Curiously, between 2011 and 2013 Tana River province had the highest contribution to the total elasmobranch landings, despite it having the lowest overall reported fisheries landings (KMALF 2015). This is possibly the result of the much greater longline prevalence in this area, although use of this gear type has subsequently dramatically decreased (KMALF 2014b).

Landings are of elasmobranchs are not reported to species level. However, recent studies suggest that hammerheads, tiger (Galeocerdo cuvier), blacktip reef (Carcharhinus melanopterus), whitetip reef (Triaenodon obesus) and grey reef sharks feature prominently, together with a number of batoids including Mobulid rays (Mobula spp.), spotted eagle (Aetobatus cf. ocellatus) and bluespotted fantail rays (Taeniura lymma) as well as large wedgefish (Rhynchobatus spp.) (Ndegwa 2015; J. Kiszka unpublished data). Other rays belonging to Dasyatidae and Myliobatidae families also appear common, having been recorded in catch assessment surveys (State Department of Fisheries and the Blue Economy unpublished data).

\section{Madagascar}

Sharks are exploited throughout Madagascan waters. However, catch and landing data are mostly available for the west coast, particularly in the southwestern (Toliara) and northwestern (Mahajunga) regions, where conditions are more favourable for fishing (Cooke 1997; Cripps et al. 2015; McVean et al. 2006; Robinson and Sauer 2013). Data relating to the volume of elasmobranch catch are scarce. Traditional fishing (i.e. from sail-powered dug-out canoes) is estimated to produce $\geq 85 \%$ of the total shark catch (Le Manach et al. 2011; Randriamiarisoa and Rafomanana 2005) and likely for the vast majority of batoid catch. In some areas elasmobranchs may account for as high as $50-60 \%$ of the overall catch (Andriantsoa and Randriamiarisoa 2013; de Feu 1998). Elasmobranch landings across all Madagascan fisheries was reported as $5650 \mathrm{mt}$ in 2014 (FAO 2016b), yet estimates suggest small-scale fisheries landings alone are in the region of $7500 \mathrm{mt} /$ year (Le Manach et al. 2011). Shark catches are reportedly decreasing in Madagascar (Cooke 1997; McVean et al. 2006) possibly a response to declining shark fin demand (Whitcraft et al. 2014) and/or intensive overfishing.

A breakdown of species composition is not available for the small-scale fisheries, however a number of case studies have been undertaken. These studies list hammerheads, silky, tiger, spottail (Carcharhinus sorrah), sliteye (Loxodon macrorhinus), whitetip reef, blacktip reef and grey reef sharks as common species in a number of areas (Andriantsoa and Randriamiarisoa 2013; Cooke 1997; Robinson and Sauer 2013; Short 2011; Smale 1998). Information regarding batoid catch is more limited, but spotted eagle, thornback (Raja clavata) and bluespotted fantail rays, various guitarfish (Rhinobatidae spp.) and large wedgefish (Rhynchobatus spp.) are also captured (Cooke 1997), with Mobula spp. reported anecdotally (Heinrichs et al. 2011).

\section{Mauritius}

Mauritius reported artisanal landings of $0.456 \mathrm{mt}$ of elasmobranchs in 2013 (Albion Fisheries Research Centre unpublished data), representing around $0.8 \%$ of the total fisheries landings by weight. In contrast, interview surveys suggest around 6000 elasmobranchs are caught annually (Poonian 2015). Whilst interview surveys are likely an unreliable way to estimate total catch effectively, the magnitude of difference suggests official reports are substantial underestimates.

The reported landings in 2013 is a $97 \%$ decrease from the $16.725 \mathrm{mt}$ in 2000 and follows general declines in landings across the Mauritian fisheries since the mid-2000's (FAO 2016b). Over this period around $85 \%$ of elasmobranch landings originated from line gears (representing $0.95 \%$ of the total line fisheries landings), whereas landings from net gears was disproportionally lower at around $7 \%$ of total elasmobranch landings (representing $0.1 \%$ of the total net fisheries landings). Basket traps account for the remaining portion, probably impacting smaller, 
benthic species, and may represent a threat to small batoids in particular. Hammerhead and tiger sharks are by far the most common species reported (Poonian 2015). Further, Mobula spp. were the only batoid reported in the catch. Ease of identification for these species likely heavily biases interview responses and so inevitably overestimates their importance in the fisheries.

Mayotte

Traditionally fishers have exploited the species-rich lagoon surrounding the island. However, decreasing catches in reef habitats (Guézel et al. 2009) and modernisation of fishing gears have resulted in a shift towards offshore pelagic resources, evidenced by the proliferation of pelagic teleost and elasmobranch species in their landings (FAO 2016b). It seems likely that significant loss of coastal/inshore elasmobranch species may have already taken place and remaining lagoon-based small-scale fisheries may be continuing to impact on or at least hindering the recovery of these stocks.

The shift towards a pelagic fishery means both competition and shared stock resources with the regional industrial fisheries. An investigation of the expanding longline small-scale fisheries of Mayotte revealed high abundance of silky, blue, scalloped hammerhead (Sphyrna lewini) and oceanic whitetip sharks in the catch, with pelagic stingrays (Pteroplatytrygon violacea) being the only batoid representative (Kiszka et al. 2010). The study showed that elasmobranchs comprised $24.6 \%$ of the catch. Whilst the fisheries themselves are dominated by handlines (both static and trolled) (Table 1) the composition is potentially similar to that of the longlines and so these may reflect the fisheries as a whole. Most, if not all, elasmobranch catch is discarded, of which $16.1 \%$ were dead (Kiszka et al. 2010). If this is representative of the fisheries as a whole, elasmobranchs discarded as dead would represent $5 \%$ of total catch of pelagic species (880 mt landed in 2014). This suggests that the reported landings of elasmobranchs $(11 \mathrm{mt}$ in 2014), are a significant underestimate of the true catch, perhaps by $75 \%$ or more.

\section{Mozambique}

Significant improvement in the monitoring and estimation of small-scale fisheries landings has been made in Mozambique (Dias and Afonso 2011; Doherty et al. 2015). Partial elasmobranch disaggregation in overall fisheries data is available through the FAO, with shortfin mako (Isurus oxyrinchus) and blue shark landings available separately in 2014 accounting for $26.3 \%$ of elasmobranch landings (FAO 2016b). Previously, separate landings data for copper (Carcharhinus brachyurus), silky and oceanic whitetip sharks have also been provided. However, at least for the small-scale fisheries in some provinces, data are available for a further 15 shark species and for spotted eagle ray (Instituto Nacional de Investigação Pesqueira unpublished data). This represents a significant step forward in the fisheries landings data resolution compared to other SWIO nations, though further disaggregation of species, and batoids in particular, is desirable. This is especially true for Mobula spp., for which Mozambique has a targeted sustenance fishery (Marshall et al. 2011) and possible gill plate trade (Heinrichs et al. 2011).

Over $98.8 \%$ of the $854 \mathrm{mt}$ of elasmobranch landings reported in 2014 originates from small-scale fisheries (Instituto Nacional de Investigação Pesqueira unpublished data). The majority comes from the dominant beach seine fishery, of which $92 \%$ of landings were reportedly spotted eagle ray, clearly highlighting this fishery as a specific threat to this species. Whilst the beach seine fishery is the most important component by virtue of its size (accounting for $46.4 \%$ of small-scale fisheries landings in 2014), much higher CPUE rates for elasmobranchs are seen in the bottom set gillnet sector (Instituto Nacional de Investigação Pesqueira unpublished data). This further emphasizes the apparent threat this gear poses to elasmobranchs at a regional level.

The validity and accuracy of both the FAO and the official Mozambique small-scale fisheries datasets, is difficult to assess. Aside from the probable significant under-reporting, there are serious discrepancies both between and within data sets. The small-scale fisheries elasmobranch landings data are often much larger than that of the total reported amounts through the FAO, in the case of 2011 by over $200 \mathrm{mt}$ (FAO 2016b; Instituto Nacional de Investigação Pesqueira unpublished data). There are also significant variations between years e.g. in 2013 bottom set gillnet landings were reported as $534.1 \mathrm{mt}$, yet in 2012 and 2014 only 142.6 and $141.1 \mathrm{mt}$ were reported, respectively. In addition, the only known estimate of shark catch in the small- 
scale fisheries was $2186 \mathrm{mt}$ from 1993, far in excess of both current and historical landings figures for the whole fisheries sector (Sousa et al. 1997). It is clear that these inconsistencies and the identification of their underlying drivers must be resolved as an urgent priority.

\section{La Réunion}

La Réunion does not currently record the landings of elasmobranchs in its small-scale fisheries; therefore, no official estimates exist (L'Institut Français de Recherche pour l'Exploitation de la Mer personal communication). The fisheries are dominated by longline and trolled handline ( $\sim 77.5 \%$ of catch) and so it is possible that elasmobranchs, particularly sharks, are an important constituent of the catch. The restricted shelf system around La Réunion is thought overfished and has been exploited historically (Le Manach et al. 2015). Since 2011, tiger and bull sharks (Carcharhinus leucas) have been the cause of increasing numbers of reported attacks on bathers and surfers, resulting in increasing efforts to reduce numbers of these species (Lemahieu et al. 2017; L'Institut de Recherche pour le Développement personal communication). However, no statistics are currently available and the magnitude of culling is unknown.

\section{Seychelles}

Fishing for elasmobranchs, primarily for finning, has been ongoing since the 1920s. Since declines in the 1950s, elasmobranchs have shifted towards incidental catch (Fowler et al. 2005), though targeted fisheries still exist. In 2014 elasmobranchs accounted for approximately $1 \%$ of total small-scale fisheries landings (SFA 2015). Landings appear to be seasonal, peaking during the months of July and August (Online Resource 6). This pattern is likely driven by the increased catches of hammerhead sharks during this time (particularly S. lewini and S. mokarran), a fishery that is believed to be sustainable (Nevill et al. 2007). Breakdown of effort and landings by gear in the official reports are insufficient to allow for analyses of historical CPUE across the fisheries. A lack of species level identification in landings data has been identified as impeding effective management in the Seychelles (Nevill et al. 2007). It is suggested that the most commonly caught are spottail and grey reef sharks in inshore waters (Fowler et al. 2005), though interviewed fishers reported tiger and sandbar sharks (Carcharhinus plumbeus) as most common (Nevill et al. 2007).

Currently there is an encouraged expansion of small-scale fisheries towards targeting pelagic finfish. This includes a development fund providing access to loans for purchasing/upgrading to longlines (Seychelles Fishing Authority personal communication). This could increase pressure on oceanic elasmobranchs, with catch composition mirroring that of the semi-industrial pelagic longliners, which report high landings of silvertip (Carcharhinus albimarginatus) and oceanic whitetip sharks (Nevill et al. 2007). Given the current lack of detailed catch statistics these developments need to be monitored closely.

\section{Tanzania (including Zanzibar)}

The catch of elasmobranchs in small-scale fisheries is significant and, at least in Zanzibar, shows signs of overexploitation and partial collapse (Jiddawi and Shehe 1999). Information regarding the catch composition of these fisheries is limited. In mainland smallscale fisheries, 11 species are commonly caught (Barnett 1997). These are predominantly requiem sharks, both oceanic and coastal (including coral reef associated), alongside hammerhead, milk (Rhizoprionodon acutus) and whitetip reef sharks. Large wedgefish (Rhynchobatus spp.) have also been reported. In Zanzibar, at least 21 elasmobranch species are caught (Barrowclift et al. 2017). A market sampling survey in 2004 identified milk, grey reef and black tip reef sharks as the most common species, with various wedgefish including bottlenose and/or whitespotted and bowmouth (Rhina ancylostoma) and Zanzibar guitarfish (Acroteriobatus zanzibarensis) also present in relatively high numbers (Schaeffer 2004). Other batoids were not recorded, however it is known that various Dasyatidae species dominate the batoid catch (Barrowclift et al. 2017). Mobula spp. are caught in both mainland and Zanzibari small-scale fisheries (Heinrichs et al. 2011; A. Temple unpublished data).

In mainland small-scale fisheries, shark catches are common through most of the year, reduced only when the weather restricts fishing activity (Barnett 1997). In Zanzibar catches of sharks appear seasonal, being highest during the north-east monsoon, particularly 
between January and May (Barnett 1997; Schaeffer 2004). However, there is insufficient information available to suggest that elasmobranch abundance is related to season. More likely is that seasonal weather precludes the use of certain gears and/or fishing locations, so impacting elasmobranch captures.

Use and value

Elasmobranchs are generally considered a target species throughout SWIO small-scale fisheries (Cooke 1997; Jiddawi and Shehe 1999; Maoulida et al. 2009; Poonian 2015; Wekesa 2013). Often they are taken as a desired constituent of a multi-species fishery also targeting moderate-to-large pelagic or reef fish species, rather than in a dedicated elasmobranch fishery. Finning is relatively rare in the region's small-scale fisheries, with the majority of catch landed whole and fully utilised (Wekesa 2013; A. Temple personal observation). However, finning does occur in parts of Mozambique and Madagascar where dedicated fisheries with formal processing and export markets exist (Cripps et al. 2015; Pierce et al. 2008). These practices present further difficulties in documenting and assessing catch. Currently, there is little evidence of demand for Mobula spp. gill plates emanating from the SWIO region (Cisneros-Montemayor et al. 2013), with the exception of small exports from Mozambique (Dent and Clarke 2015). However, should this change it will likely increase fisheries pressure exerted on these species. Where export markets for elasmobranch products do exist, shark and wedgefish fins hold substantially higher value relative to the rest of the body (Online Resource 4). However, readily available data on landings volume and value are limited e.g. the only reports to the FAO were from Madagascar and Seychelles in 2013 (FAO 2016b). Further, there is a lack of information regarding supply chains and the contribution from small-scale fisheries to these.

As a source of protein elasmobranch meat is relatively cheap (Online Resource 4) in comparison with teleosts (e.g. MFR 2004, 2012), and may form an important nutritional component in the diets of those supplied by and dependant on small-scale fisheries. Lack of access to cold storage facilities requires that meat is often either sold fresh locally or air/salt dried in preparation for sale at distant markets or export (Cripps et al. 2015). Value of elasmobranch products depends on a number of factors including perceived quality (species and preparation related), route of sale and cultural and religious influences, such as Ramadan, which affect both supply and demand (Barrowclift et al. 2017; Cripps et al. 2015). It is therefore important to further our understanding of elasmobranch value in SWIO small-scale fisheries, and their markets and drivers, if we are to assess the socioeconomic importance of these fisheries and their component species. Ultimately, a proper understanding of the socio-economic value of the fisheries is vital to the design and implementation of any successful management strategy.

\section{Fisheries policy and management in the southwestern Indian Ocean: implications for vulnerable marine megafauna in small-scale fisheries}

Formal governance arrangements in the fisheries sector are a fundamental component in the sustainable use of fisheries stocks. Good governance, policies and resultant effective management of fisheries stand to create a strong platform from which sustainable species harvest can be achieved and controlled. It is therefore vital that we understand both the principles upon which policies are built and what management is in place to achieve these goals with regard to vulnerable marine megafauna in the SWIO.

\section{International}

Many SWIO nations are party to international fisheries-specific agreements that have implications for both general fisheries policy and management and vulnerable marine megafauna specifically (Online Resource 5). Primary amongst these is the United Nations Fish Stocks Agreement (UNFSA) 1995, which obligates that parties undertake ecosystembased and precautionary approaches to migratory fish stock management (UN 2016). This agreement increases the responsibility of nations over their fisheries and their enforcement of laws within them, and strengthens the roles of regional fisheries bodies. Given the overlap in vulnerable marine megafauna species between SWIO nations (Table 3; Bourjea 2015; Kiszka 2015; Kiszka and van der Elst 2015), and absence of stock delineations for the majority of 
species, there is a clear need to consider these as shared resources until clarification can be achieved. Concurrently, the signatory status, ratification and accession to the Port State Measures Agreement by many SWIO nations (FAO 2016a), signifies increasing regional efforts to tackle illegal, unlicensed and unreported (IUU) fisheries. These fisheries are rife in the SWIO region (Agnew et al. 2009) and so likely have substantial impacts on vulnerable marine megafauna species and marine ecosystems in general. Better control and documentation of these IUU fisheries will therefore be vital in managing both vulnerable marine megafauna fisheries and the fisheries as a whole in the SIWO region.

At a regional level, SWIO marine environmental policies are largely outlined by a number of conventions and agreements. The most ubiquitous of these is the Nairobi Convention 2010 (formally, the Amended Convention of the Protection, Management and Development of the Marine and Coastal Environment of the Western Indian Ocean) to which all SWIO nations are party. Broadly, the convention places onus on the party states to work, both individually and cooperatively, in an effort to sustainably maintain, manage and develop their marine and coastal ecosystems (UNEP 2010). It highlights a recognition and willingness of SWIO nations to view the marine environment as an inter-linked and shared resource. This outlook is pivotal to any meaningful management of the region's fisheries, including those which catch vulnerable marine megafauna.

There are also specific international agreements dealing with vulnerable marine megafauna to which SWIO nations are contracted. The Convention on International Trade in Endangered Species of Wild Fauna and Flora (CITES) (CITES 2016) make international trade of any marine mammal or sea turtle illegal. Further, trade of 17 species of elasmobranch (12 of which are known to occur in the SWIO) are controlled to varying extents. In this regard these species receive some level of protection through control over commercial exploitation for international trade. The Indian Ocean Cetacean Sanctuary, designated and established in 1979 by the International Whaling Commission (IWC), covers the entirety of the Indian Ocean south to $55^{\circ} \mathrm{S}$ and prohibits commercial whaling. However, it does not provide protection for smaller cetaceans nor does it identify critical habitats for cetaceans (IWC 1980), a significant roadblock to achieve effective implementation. Currently Kenya and Tanzania are the only SWIO nation members of the IWC. The Conservation of Migratory Species Memoranda of Understandings (CMS MoUs) seeking to encourage protection of and promote stock recovery for sea turtles, dugongs and sharks, have been effective since 2001, 2007 and 2010 respectively. Both the sea turtle and dugong agreements boast wide coverage, with only La Réunion absent as a signatory on the dugong $\mathrm{MoU}$, as the species is absent from its waters (CMS 2016a, b). Conversely, few SWIO nations have signed the CMS MoU for sharks (Online Resource 5), raising some concern over the political willingness of SWIO nations to sustainably manage these species, though it must be considered that this MoU has only been created very recently (CMS 2016c). Those SWIO countries yet to sign the CMS MoUs should be encouraged too do so, as the commission and these agreements represent a pathways for facilitating the conservation (in its widest sense) of vulnerable marine megafauna in the region.

\section{National directed management}

At a national level there are varying degrees of directed management relating to vulnerable marine megafauna species. Dugongs and cetaceans are protected by law throughout the SWIO and for sea turtles, intentional catch, egg poaching and sale is widely prohibited (Table 4). Further protection is offered through anti-disturbance regulations in some areas, both site-specific (in various MPAs) and nationally in the case of Mozambique (Marine and Coastal Environment Regulation, Decree 45/2006). Only the Seychelles do not offer complete protection, with green and hawksbill protected but not loggerhead, leatherback or olive ridley, despite their presence (although not nesting) in the SWIO region (Frazier 1984; Remie and Mortimer 2007). A National Plan of Action (NPOA) for sea turtles has been implemented by France, covering Mayotte, the French dispersed islands (Tromelin, Glorieuses, Juan de Nova, Bassas da India and Europa) and La Réunion, and a NPOA is under discussion for Tanzania (Igulu and El Kharousy 2015).

Conversely, current regulations regarding elasmobranchs are very limited for the small-scale fisheries of the region (Table 4) and where they do exist their effectiveness is often questioned. For example, as of 
Table 4 Legal status and related punishments regarding vulnerable marine megafauna in the small-scale fisheries of the South Western Indian Ocean

\begin{tabular}{|c|c|c|c|c|}
\hline Country & Sea Turtle & Cetaceans & Dugong & Chondrichthyans \\
\hline Comoros & $\begin{array}{l}\text { Prohibited-Punishable } \\
\text { by imprisonment (Soilihi } \\
\text { 2014) }\end{array}$ & Prohibited & Prohibited & $\begin{array}{l}\text { Partial-Thresher shark } \\
\text { prohibited (Soilihi 2014) }\end{array}$ \\
\hline Kenya & $\begin{array}{l}\text { Prohibited-The Wildlife } \\
\text { (Conservation and } \\
\text { Management) Act of } \\
2013 \text { (revised), The } \\
\text { Fisheries Act Cap } 378 \\
\text { revised } 2012\end{array}$ & $\begin{array}{l}\text { Prohibited-Kenya } \\
\text { Fisheries Act 2012, The } \\
\text { Fisheries Management } \\
\text { and Development Bill, } \\
\text { 2014-1 year } \\
\text { imprisonment and/or } \\
\text { 100,000 KES fine }\end{array}$ & $\begin{array}{l}\text { Prohibited-Kenya } \\
\text { Fisheries Act 2012, The } \\
\text { Fisheries Management } \\
\text { and Development Bill, } \\
\text { 2014-1 year } \\
\text { imprisonment and/or } \\
\text { 100,000 KES fine }\end{array}$ & None \\
\hline Madagascar & $\begin{array}{l}\text { Prohibited-Décret no } \\
2006\end{array}$ & Prohibited & Prohibited & None \\
\hline Mauritius & $\begin{array}{l}\text { Prohibited-Mauritian } \\
\text { Fisheries and Marine } \\
\text { Resources Act 2007- } \\
\text { 100,000 MUR fine }\end{array}$ & $\begin{array}{l}\text { Prohibited-Mauritian } \\
\text { Fisheries and Marine } \\
\text { Resources Act 2007- } \\
\text { 100,000 MUR fine }\end{array}$ & $\begin{array}{l}\text { Prohibited-Mauritian } \\
\text { Fisheries and Marine } \\
\text { Resources Act 2007- } \\
\text { 100,000 MUR fine }\end{array}$ & $\begin{array}{l}\text { Partial—Fishing licence not } \\
\text { granted for targeting } \\
\text { sharks (Soondron et al. } \\
\text { 2013) }\end{array}$ \\
\hline Mayotte & $\begin{array}{l}\text { Prohibited-National } \\
\text { decree (October 14th } \\
\text { 2005) }\end{array}$ & $\begin{array}{l}\text { Prohibited-National } \\
\text { decree (July 27th 1995) }\end{array}$ & $\begin{array}{l}\text { Prohibited-National } \\
\quad \text { decree (July 27th 1995) }\end{array}$ & None \\
\hline Mozambique & $\begin{array}{l}\text { Prohibited_Law of } \\
\quad \text { Regulation Forests and } \\
\text { Wildlife (Decree No. } \\
\text { 12/2002)_-25,000 MZN } \\
\text { fine }\end{array}$ & Prohibited & $\begin{array}{l}\text { Prohibited_Law of } \\
\quad \text { Regulation Forests and } \\
\text { Wildlife (Decree No. } \\
\text { 12/2002)_50,000 MZN } \\
\text { fine }\end{array}$ & None \\
\hline La Réunion & $\begin{array}{l}\text { Prohibited-National } \\
\text { decree (October 14th } \\
\text { 2005)_5000 EUR or } \\
6 \text { month imprisonment }\end{array}$ & $\begin{array}{l}\text { Prohibited-National } \\
\text { decree (July 27th } \\
\text { 1995)—5000 EUR or } \\
6 \text { month imprisonment }\end{array}$ & $\begin{array}{l}\text { Prohibited-National } \\
\text { decree (July 27th } \\
\text { 1995)_5,000 EUR or } \\
6 \text { month imprisonment }\end{array}$ & $\begin{array}{l}\text { Partial_Préfecture de La } \\
\text { Réunion, arrêté no 06- } \\
\text { 2412/SG/DRCTCV } \\
\text { 2006_Due to ciguatera } \\
\text { poisoning risk, } \\
\text { hammerhead sharks } \\
\text { (Sphyrna spp.) cannot be } \\
\text { commercialised }\end{array}$ \\
\hline Seychelles & $\begin{array}{l}\text { Prohibited-Fisheries Act } \\
2014 \text { Regulations- } \\
\text { green and hawksbill } \\
\text { turtles only }\end{array}$ & Prohibited & Prohibited & $\begin{array}{l}\text { Partial_Fisheries Act } 2014 \\
\text { Regulations_Baiting and } \\
\text { chumming for shark } \\
\text { illegal 450,000 SCR fine. } \\
\text { Gillnetting for shark } \\
\text { prohibited }\end{array}$ \\
\hline $\begin{array}{l}\text { Tanzania } \\
\text { (mainland) }\end{array}$ & $\begin{array}{l}\text { Prohibited-The Fisheries } \\
\text { Act, } 2003 \text { (Regulations } \\
\text { 2005)_-200,000 TZS } \\
\text { fine or } 3 \text { month } \\
\text { imprisonment }\end{array}$ & Prohibited & Prohibited & $\begin{array}{l}\text { Partial-Export of meat and } \\
\text { fins not permitted. Whale } \\
\text { shark catch prohibited. }\end{array}$ \\
\hline $\begin{array}{l}\text { Tanzania } \\
\text { (Zanzibar) }\end{array}$ & Prohibited & Prohibited & Prohibited & $\begin{array}{l}\text { Partial-Licences for fin } \\
\text { export no longer issued }\end{array}$ \\
\hline
\end{tabular}

2016, licences are no longer being distributed for shark fin export from Zanzibar (Ministry of Agriculture, Livestock and Fisheries, personal communication), effectively making the trade illegal. However, post- harvest removal of fins from landed elasmobranchs to supply international trade (including from CITES listed species) still occurs in spite of these restrictions (A. Temple personal observation). Unlicensed 
shipping of shark fins to Kenya is thought common (Fowler et al. 2005) and may be continuing to provide the export route out of the country. In spite of the general lack of regulations for the elasmobranch small-scale fisheries, NPOAs have been or are currently in development for most SWIO nations (Table 4), with Kenya and Mozambique projecting completion by the end of 2017 (Chacate and Mutombene 2015, Wekesa 2014), suggesting widespread recognition of the threats faced by these species and a movement towards addressing the issues. As with other regulations pertaining to many small-scale fisheries in the region, implementation is challenged by management authorities' lack of infrastructure and resources to ensure compliance, compounded by the generally open-access nature of these fisheries.

\section{National indirect management}

There are also some regulations and initiatives which likely indirectly impact interactions between smallscale fisheries and vulnerable marine megafauna in the SWIO (see http://www.wiofish.org for comprehensive information on prohibited fisheries and gear restrictions in the SWIO). For example, in Mauritius, the Fisheries and Marine Resources Act 2007 prohibits the use of certain fishing gears. Most relevant to vulnerable marine megafauna is the ban on the use of driftnets (defined there as a net exceeding $250 \mathrm{~m}$ in length, fitted with floats or weights to make it hang vertically in the water column) with a fine of up to 20,000 USD if found in breach of the Act. Further it prohibits the use of shorter net gears ("large nets" and "gillnets" less than $250 \mathrm{~m}$ in length) for 5 months of the year (October-February, 500,000 MUR/ 14,000 USD fine) and licences may only be issued for use of 10 "large nets" and 5 "gillnets" at any one time in the lagoon waters of Mauritius. Given these nets form the principal gear threats to vulnerable marine megafauna at the global scale, this likely has a major impact on their interactions with the fisheries in Mauritius. In Kenya (Fisheries Act Cap 378, Kenya Gazette Notice No. 7565) and Tanzania (Fisheries Act Regulations, 2003) the use of mono-filament nets is prohibited, though compliance is poor (KMALF 2014b; A. Temple personal observation), resultant changes in gear use could impact the catches of vulnerable marine megafauna species susceptible to alternate gears whilst protecting those species susceptible to the mono-filament nets.
Beach seine nets are prohibited in Kenya, Tanzania and Comoros, which reduces fishing pressure on some coastal elasmobranchs, but again, ensuring compliance is problematic.

\section{Discussion}

This review highlights the severely limited understanding of vulnerable marine megafauna and their interactions with the small-scale fisheries of the SWIO resulting from a lack of robust data. Yet, where evidence exists, there are indications of population declines due to fisheries interactions (Amir et al. 2002; Cooke 1997; FAO 2016b; Jiddawi and Shehe 1999; McVean et al. 2006; Muir and Kiszka 2012). Furthermore, it is clear that at both national and regional levels, current small-scale fisheries monitoring practices and management are insufficient to assess and ensure the long-term sustainability of small-scale fisheries and the vulnerable marine megafauna species impacted by them. Therefore, there is a clear regional priority to collect much more information on smallscale fisheries characteristics, species catch, landings and composition, as well as data regarding vulnerable marine megafauna gear-interactions. These data are required to undertake a robust and detailed analysis at both regional and area-specific spatial scales, without which informed, evidence-based management and facilitating policies cannot be achieved effectively. As such, and in the absence of truly precautionary management, vulnerable marine megafauna must be considered at high risk of on-going overexploitation at both the national and regional scale in the SWIO.

Improved monitoring and assessment of smallscale fisheries both at national and regional levels is critical in achieving sustainable harvest of fisheries resources, including vulnerable marine megafauna. It is probable that the majority of these fisheries stocks are shared given: the highly mobile, transboundary nature of many species (e.g. Table 3); few geographical barriers in the SWIO; migrant fishing; and the notion of Economic Exclusive Zones being at best flexible when regarding small-scale fisheries. In light of this there is a clear need for SWIO nations to begin identification and delineation of stocks and to devise a joint strategy defining protocols for collection and reporting of small-scale fisheries data. At the heart of any such strategy must be a consensus on minimum 
data requirements (landings, effort, gear composition and their breakdowns), standardised metrics and methodologies used for collecting the data. Standardised reporting procedures and formats would also be of great benefit, allowing data to be compiled and synthesised with greater ease. Beyond any agreed minimum, nations should be encouraged to collect further data as far as is feasible, particularly where these data address specific issues or interests of each party or the region. Where such issues may have wider applicability an open discussion regarding metrics and methods would benefit all parties. Ultimately such changes would aid the understanding and management of small-scale fisheries and assist the decision-making processes, with implications for the long-term regional sustainability of the sector. However, currently there is no regional body with the ability to make binding decisions on such issues, the Indian Ocean Tuna Commission's (IOTC) mandate is too restricted and the Southern Indian Ocean Fisheries Agreement's (SIOFA) membership only has partial SWIO coverage. Perhaps best placed to facilitate such changes is the South West Indian Ocean Fisheries Commission (SWIOFC), through its role as an advisory body, in conjunction with expanding the mandate of the IOTC and through the ability of IOTC and SIOFA to make binding decisions (van der Geest 2017).

CPUE is a fundamental measure used to monitor stock health and fisheries sustainability (Maunder and Punt 2004; Sparre and Venema 1998), yet for most SWIO small-scale fisheries such data cannot be generated. To create an accurate and usable CPUE time series, effort data must accommodate changes in fisheries dynamics, behaviour and power. To this end measurement of fishing effort requires four main data types: gear type including specificity (e.g. mesh size, hook size, mono/multifilament etc.); fishing mode (e.g. active or passive) to allow proper categorisation of the fisheries; gear characteristics (e.g. net dimensions, number of hooks etc.); and active fishing effort (e.g. soak times, trawl speeds/distance etc.). Currently data collected for small-scale fisheries in SWIO nations consistently lacks one or more of these aspects (Table 1, Online Resource 3). For example, in five nations (Comoros, Kenya, Madagascar, Tanzania mainland and Zanzibar) effort is either recorded and not compiled or not recorded at all. Whereas, in others fishing effort is given in trips, sets, active vessels and fisher-days (Online Resource 3), none of which are suited for accurate estimation of fishing effort due to large potential variation within these measures e.g. trips may last for hours or days. Thus the utilisation of fisheries data for informing management objectives, targets and strategies is restricted.

Some of these effort monitoring weaknesses could be addressed through relatively minor changes to current monitoring protocols. Detailed gear specifications and fishing modes could be incorporated into national census/frame surveys in which data on gear type are already routinely collected (Table 1). Active fishing effort data are however more difficult to obtain, especially given the informal nature of many smallscale fisheries. It is perhaps inevitable that in the short term active fishing effort data may need to be generated through declarations by fishers along with evidence-based assumptions until a more formalised system is possible. Alternatively, CPUE estimates could be generated through fisheries-independent data (Sparre and Venema 1998), however this can be costly and so is likely unfeasible for most SWIO nations.

Regarding vulnerable marine megafauna in SWIO small-scale fisheries, generally catch and landings data are relatively poor and where available are often lacking in both species composition and catch-by-gear data. This lack of information severely limits the ability to identify and manage at-risk species and stocks, including assessment of gear and area-specific threats. Despite the general paucity of data, it is clear that in a number of areas catches are in decline and some populations are known to be overexploited (Amir et al. 2002; Cooke 1997; FAO 2016b; Jiddawi and Shehe 1999; McVean et al. 2006; Muir and Kiszka 2012; Nevill et al. 2007). Thus, there is an urgent need for proper assessment of vulnerable marine megafauna in SWIO small-scale fisheries. Catch and landings data which do exist show substantial numbers of large oceanic shark species in the small-scale fisheries (Andriantsoa and Randriamiarisoa 2013; Barnett 1997; Cooke 1997; FAO 2016b; Kiszka et al. 2010; Maoulida et al. 2009; Ndegwa 2015; Nevill et al. 2007; Poonian 2015; Robinson and Sauer 2013; Schaeffer 2004; Smale 1998; Soilihi 2014), indicating increasing competition for resources with the industrial fisheries. Increasing competition for these stocks is concerning for two main reasons: increased pressure on stocks that are already thought to be overharvested and at high extinction risk (García et al. 2008); and it indicates a shift towards fishing further offshore by the small- 
scale fisheries sector, a phenomenon seen elsewhere in instances where inshore stocks may have become depleted.

Comparatively little information on the marine mammal, sea turtle and batoid and chimera catch components of the fisheries are available, though given the general confinement of chimera to deeper waters (Kyne and Simpfendorfer 2007) they are unlikely affected by small-scale fisheries in the SWIO region. There is therefore a clear need to address this data vacuum. With regards to marine mammals and sea turtles specifically, understanding of catch is further limited as a result of their legal status, creating a reluctance to declare catches. Governmental departments are therefore poorly placed to generate these data and so they should represent a priority focus for collaborative work with independent researchers and NGOs.

Currently the data regarding SWIO small-scale fisheries interactions with vulnerable marine megafauna are unable to support management aimed at safe sustainable exploitation of these resources, yet there is clear evidence that vulnerable marine megafauna species are at risk from these fisheries. As such, and in accordance with the UN Fisheries Stocks Agreement 1995 and the Nairobi Convention, a precautionary conservation-minded approach is mandated to safeguard vulnerable marine megafauna until such time as robust evidence-based management strategies for sustainable exploitation can be achieved. If such measures are not taken, SWIO nations will be failing in their duty of care to both to the fishers and communities that rely on these resources and to the vulnerable marine megafauna themselves by failing to protect the biodiversity of their marine environment.

At the national scale, effective management strategies require a proper understanding of the human elements of the fisheries (Gray 2005; Kooiman et al. 2005). Fishers face an increasing variety of changing socio-economic conditions related to overexploitation, climate change, globalization, and conservation of marine biodiversity. Understanding the socioeconomic importance of vulnerable marine megafauna species across stakeholder groups, including perceptions and attitudes (both cultural and individual) towards these species, as well as how fishers will respond to potential ecosystem and institutional changes is critical to better managing these fisheries, achieving fishers acceptance of and compliance with management strategies and improving the livelihoods of those dependent on fisheries supply chains (Daw et al. 2012). Further, effective and appropriate enforcement is vital for sustainable management practices to be implemented, whether this be establishment or community driven, and presents a significant challenge for SWIO governments. Without this, dissent and non-compliance (Peterson and Stead 2011) can become wide-spread issues (Hauck 2008; Keane et al. 2008; Nielsen and Mathiesen 2003) and management strategies can be rendered ineffective. This review highlights that a significant gap in information exists in describing existing and shifting dependency of fishers in SWIO small-scale fisheries which, if collected alongside the much needed ecological data on fisheries, could provide better context for introducing effective management measures for vulnerable marine megafauna.

In the face of the numerous data gaps and taking into context infrastructure and the resource constraints present in SWIO nations, there is a clear need to identify appropriate low-cost methods to assess the magnitude of vulnerable marine megafauna catch in small-scale fisheries and to mitigate these when they are unsustainable. Critical assessment of various data collection methods (e.g. vessel-based observer programs, interview surveys, landing site data collection), incorporating time and cost factors, is vital in facilitating informed decision making, through which challenges can addressed in both the short and long term using the appropriate methodological tools. Further, for species at highest risk, precautionary mitigation strategies need to be considered. Sea turtles, marine mammals and several species of elasmobranchs are of primary concern in this regard and catch mitigation methods (e.g. turtle excluding devices, weak links for nets and acoustic alarms) are already available for some of them (e.g. Barlow and Cameron 2003; Gilman et al. 2006; Ward et al. 2008). However, many of these methods are costly, and so there is a clear need and an opportunity to develop minimum-cost methods that are feasible for implementation in small-scale fisheries in the SWIO and globally. As a Regional Fisheries Authority, the SWIOFC and its working groups are well placed to facilitate the promotion and co-ordination of these initiatives, and to undertake and/or guide regular assessments of small-scale fisheries in the SWIO, in order to address questions of sustainability of vulnerable megafauna, and of the fisheries themselves. 


\section{Conclusions}

This review highlights information needed to reconcile vulnerable marine megafauna conservation with small-scale fisheries demands and where it is lacking in the SWIO. Here the SWIO acts as both subject and case study in the broader issue of marine species conservation goals and the needs of those communities that rely on them, especially in data poor and developing regions. In addressing these issues, it is essential that solutions be built properly upon principles that balance environmental and human (economic and social) needs and are grounded in realism. Both funding and the time-scales in which to find effective solutions are limited, particularly in developing regions, and so research must be strictly prioritised towards practical and goal-oriented outputs that properly account for and engage stakeholders. Given the potentially dire situation for several vulnerable marine megafauna species it is critical to address priority baseline data gaps and their associated challenges. Governments, NGOs, independent researchers and research institutions and other stakeholders must act collaboratively to achieve common goals and ensure implementation of findings into effective evidencebased management, thus facilitating for a sustainable future for vulnerable marine megafauna species, the marine ecosystem and the associated livelihoods in coastal communities.

Acknowledgements The authors would like to thank the Western Indian Ocean Marine Science Association (WIOMSA) for funding the project, By-Catch Assessment and Mitigation in the Western Indian Ocean (BYCAM), under which this review has been produced. We thank the following institutions, in no particular order, for supplying information which made this review possible: Kenya Marine \& Fisheries Research Institute, Kenya State Department of Fisheries, WWF East Africa, Watamu Marine Association, Seychelles Fishing Authority, Tanzanian Ministry of Livestock and Fisheries Development, Zanzibari Ministry of Agriculture, Livestock and Fisheries, Mozambique Instituto Nacional de Investigação Pesqueira, Madagascan Ministry of Fisheries and Marine Resources, Mauritian Ministry of Fisheries and L'Institut Français de Recherche pour l'Exploitation de la Mer in La Réunion. We also would like to thank other members of the BYCAM team for their help both in collection of data and feedback on the manuscript, particularly Ms Yvette Razafindrakoto and Ms Lala Rakotoarimino of Conservation Centrée sur la Communauté (C3). Last we thank Ms Sarah E. Kenney from Newcastle University, for her assistance in the preparation of Fig. 1. This is contribution \#51 of the Marine Education and Research Center in the Institute for Water and Environment at Florida International University

Funding This study was funded by the Western Indian Ocean Marine Science Association (Grant Number MASMA/CP/2014/ 01).

\section{Compliance with ethical standards}

Conflict of interest Authors N. Wambiji, A. Brito and O. A. Amir are currently and/or have previously worked for inregion fisheries management (or related) institutions, however the authors do not believe that these current and/or past affiliations have had undue influence over the contents or interpretation of this review.

Open Access This article is distributed under the terms of the Creative Commons Attribution 4.0 International License (http:// creativecommons.org/licenses/by/4.0/), which permits unrestricted use, distribution, and reproduction in any medium, provided you give appropriate credit to the original author(s) and the source, provide a link to the Creative Commons license, and indicate if changes were made.

\section{References}

Agnew DJ, Pearce J, Pramod G, Peatman T, Watson R, Beddington JR, Pitcher TJ (2009) Estimating the worldwide extent of illegal fishing. PLoS ONE 4:e4570. doi:10.1371/ journal.pone.0004570

Fowler SL et al (2005) Sharks, rays and chimaeras: the status of the Chondrichthyan fishes. Status survey, vol 63. Status Survey. IUCN/SSC Shark Specialist Group. IUCN, Gland, Switzerland and Cambridge, UK

Amir OA (2010) Biology, ecology and anthropogenic threats of Indo-Pacific bottlenose dolphins in East Africa. Doctoral Thesis, Stockholm University

Amir OA, Jiddawi NS (2001) Dolphin tourism and community participation in Kizimkazi village, Zanzibar. WIOMSA Book Ser 1:551-560

Amir OA, Berggren P, Jiddawi NS (2002) The incidental catch of dolphins in gillnet fisheries in Zanzibar, Tanzania. West Indian Ocean J Mar Sci 1:155-162

Andriantsoa MH, Randriamiarisoa (2013) Caractérisation actuelle de la pêche maritime à Madagascar, les systèmes statistiques du MPRH et conception des activités pour le nouveau système de suivi des captures. Mise en oeuvre d'une stratégie régionale de la pêche pour la région AOAOI (IRFS) vol Mise en oeuvre d'une stratégie régionale de la pêche pour la région AOA-OI (IRFS)

Aragones LV, Lawler IR, Foley WJ, Marsh H (2006) Dugong grazing and turtle cropping: grazing optimization in tropical seagrass systems? Oecologia 149:635-647. doi:10. 1007/s00442-006-0477-1

Barnett R (1997) The shark trade in mainland Tanzania and Zanzibar. In: Marshall NT, Barnett R (eds) The trade in sharks and shark products in the Western Indian and 
Southeast Atlantic Oceans. TRAFFIC, East/Southern Africa, Nairobi, pp 39-67

Barlow J, Cameron GA (2003) Field experiments show that acoustic pingers reduce marine mammal bycatch in the california drift gill net fishery. Mar Mammal Sci 19:265-283. doi:10.1111/j.1748-7692.2003.tb01108.x

Barrowclift E, Temple AJ, Stead S, Jiddawi NS, Berggren P (2017) Social, economic and trade characteristics of the elasmobranch fishery on Unguja Island, Zanzibar, East Africa. Mar Policy 83:128-136. doi:10.1016/j.marpol. 2017.06.002

Béné C (2006) Small-scale fisheries: assessing their contribution to rural livelihoods in developing countries. FAO Fisheries Circular. No. 1008. FAO, Rome

Bourjea J (2015) 9. Sea Turtles: a review of status, distribution and interaction with fisheries in the Southwest Indian Ocean. In: Van der Elst R, Everett B (eds) Offshore Fisheries of the Southwest Indian Ocean, vol Special Publication 10. Oceanographic Research Institute, Durban, South Africa, pp 325-350

Bourjea J, Nel R, Jiddawi NS, Koonjul MS, Bianchi G (2008) Sea turtle bycatch in the West Indian Ocean: review, recommendations and research priorities. West Indian Ocean J Mar Sci 7:137-150

Bourjea J, Clermont S, Delgado A, Murua H, Ruiz J, Ciccione S, Chavance P (2014) Marine turtle interaction with purseseine fishery in the Atlantic and Indian oceans: lessons for management. Biol Conserv 178:74-87. doi:10.1016/j. biocon.2014.06.020

Burkholder DA, Heithaus MR, Fourqurean JW, Wirsing A, Dill LM (2013) Patterns of top-down control in a seagrass ecosystem: could a roving apex predator induce a behaviour-mediated trophic cascade? J Anim Ecol 82:1192-1202. doi:10.1111/1365-2656.12097

Cerchio S, Andrianarivelo N, Razafindrakoto Y, Mendez M, Rosenbaum HC (2009) Coastal dolphin hunting in the southwest of Madagascar: status of populations, human impacts and conservation actions. Paper SC61/SM15 presented to the IWC Scientific Committee, June 2009, Maderia, Portugal (unpublished) 9 pp [availabile from the Secretariat of the International Whaling Commission]

Chacate OE, Mutombene R (2015) Mozambique national report to the scientific committee of the Indian Ocean Tuna Commission, 2015. Instituto Nacional de Investigação Pesqueira

Chavance P, Herfaut J, Bourjea J, Chassot E (2014) Rapport national destiné au Comité scientifique de la Commission des thons de l'océan Indien, pour sa réunion annuelle 2013-2014. Informations sur les Pêcheries, les Recherches et les Statistiques

Church JE, Palin O (2003) The sea turtle conservation initiative in the Kiunga marine national reserve, Lamu, Kenya from February 1997 to June 2003. WWF Report

Cisneros-Montemayor AM, Barnes-Mauthe M, Al-Abdulrazzak D, Navarro-Holm E, Sumaila UR (2013) Global economic value of shark ecotourism: implications for conservation. Oryx 47:381-388. doi:10.1017/s003060531200 1718

CITES (2016) List of contracting parties. https://www.cites.org/ eng/disc/parties/chronolo.php?order=field_country_date_ of_joining\&sort=asc. Accessed 9 Nov 2016
CMS (2016a) Dugong signatories and range states. http://www. cms.int/dugong/en/signatories-range-states. Accessed 9 Nov 2016

CMS (2016b) IOSEA marine turtles. http://www.cms.int/en/ legalinstrument/iosea-marine-turtles. Accessed 9 Nov 2016

CMS (2016c) Sharks signatories and range states. http://www. cms.int/sharks/en/signatories-range-states. Accessed 9 Nov 2016

Cooke AJ (1997) Survey of Elasmobranch fisheries and trade in Madagascar. In: Marshall NT, Barnett R (eds) The trade in sharks and shark products in the Western Indian and Southeast Atlantic Oceans. TRAFFIC, East/Southern Africa, Nairobi, pp 33-38

Couturier LIE et al (2012) Biology, ecology and conservation of the Mobulidae. J Fish Biol 80:1075-1119. doi:10.1111/j. 1095-8649.2012.03264.x

Cripps G, Harris A, Humber F, Harding S, Thomas T (2015) A preliminary value chain analysis of shark fisheries in Madagascar. In: Programme for the implementation of a Regional Fisheries Strategy for the Eastern and Southern Africa-Indian Ocean Region vol SF/2015/34. Indian Ocean Commission, Ebène, Mauritius, p 82

Daw TM, Cinner JE, McClanahan TR, Brown K, Stead SM, Graham NAJ, Maina J (2012) To fish or not to fish: factors at multiple scales affecting artisanal fishers' readiness to exit a declining fishery. PLoS ONE 7:e31460. doi:10.1371/ journal.pone.0031460

de Feu TA (1998) Fisheries statistics for the large meshed gill net fishery, NorthWest Madagascar. Promotion de la Peche Maritime Traditionelle et Artisanale

de Graaf G, Garibaldi L (2014) The value of African fisheries, FAO fisheries and aquaculture circular No. 1093. Rome. http://www.fao.org/3/a-i3917e.pdf

Dent F, Clarke S (2015) State of the global market for shark products. FAO Fish Aquac Tech Pap 590:187

Dias N, Afonso P (2011) Overview of fisheries and data information. In: IndiSeas-SWIOFP meeting/workshop, 18th19th January 2011, Cape Town (South Africa)

Divetime (2016) Africa Scuba diving. http://www.divetime. com/divesites/Africa. Accessed 31 Oct 2016

Doherty B, McBride MM, Brito AJ, Le Manach F, Sousa L, Chauca I, Zeller D (2015) Marine fisheries in Mozambique: catches updated to 2010 and taxonomic disaggregation. In: Le Manach F, Pauly D (eds) Fisheries catch reconstructions in the Western Indian Ocean, 1950-2010. Fisheries Centre Research Reports, vol 23(2). Fisheries Centre, University of British Columbia pp 67-81

Dulau V, Estrade V, Fayan J (2017) Identifying key demographic parameters of a small island-associated population of Indo-Pacific bottlenose dolphins (Reunion, Indian Ocean). PLoS ONE 12:e0179780. doi:10.1371/journal. pone. 0179780

Dulvy NK et al (2014) Extinction risk and conservation of the world's sharks and rays. eLife 3:34-35. doi:10.7554/eLife. 00590

ESAP A (2005) Enquête Statistique sur l'Agriculture et la Pêche (ESAP) Mayotte 2003. N³ DAF, Direction de l'Agriculture et de la Forêt

ESRI (2014) Country shapefiles. http://www.arcgis.com. Accessed 29 Nov 2016 
FAO (2010) Guidelines to reduce sea turtle mortality in fishing operations. FAO Fisheries and Aquaculture Department, Rome

FAO (2012) Food and Agriculture Organization of the United Nations, FAO yearbook: fisheries and aquaculture statistics. http://www.fao.org/3/a-i3740t.pdf. Accessed 7 Mar 2016

FAO (2016a) Agreement on port state measures to prevent, deter and eliminate illegal, unreported and unregulated fishing. http://www.fao.org/fileadmin/user_upload/legal/docs/ 037s-e.pdf. Accessed 9 Nov 2016

FAO (2016b) Fishery and aquaculture statistics. Global capture production 1950-2014 (FishstatJ). In: FAO Fisheries and Aquaculture Department [online or CD-ROM]. FAO. http://www.fao.org/fishery/statistics/software/fishstatj/en

FAO (2016c) Small-scale fisheries_-people and communities. FAO fisheries and aquaculture website, Rome. http://www. fao.org/fishery/ssf/people/en. Accessed 28 Sept 2016

Fennessy ST (1994) Incidental capture of elasmobranchs by commercial prawn trawlers on the Tugela Bank, Natal, South Africa. S Afr J Mar Sci 14:287-296. doi:10.2989/ 025776194784287094

Frazier J (1984) Marine turtles in the Seychelles and adjacent terretories. In: Stoddart DR (ed) Biogeography and ecology of the Seychelles Islands. Dr. W. Junk Publishers, The Hague, pp 417-468

Gallagher AJ, Hammerschlag N (2011) Global shark currency: the distribution, frequency, and economic value of shark ecotourism. Curr Issues Tour 14:797-812. doi:10.1080/ 13683500.2011 .585227

García VB, Lucifora LO, Myers RA (2008) The importance of habitat and life history to extinction risk in sharks, skates, rays and chimaeras. Proc R Soc B Biol Sci 275:83-89. doi:10.1098/rspb.2007.1295

Gilman E et al (2006) Reducing sea turtle by-catch in pelagic longline fisheries. Fish Fish 7:2-23. doi:10.1111/j.14672979.2006.00196.x

Gray TS (2005) Participation in fisheries governance. Springer, Dordrecht. doi:10.1007/1-4020-3778-3

Guézel R, Quartararo A, Aboutoihi L, Saindou K, Salaün P, Ybrahim B, Arnaud JP (2009) Richesses de Mayotte-Parc naturel marin de Mayotte-Les hommes et l'océanMission d'étude pour la création d'un parc naturel marin à Mayotte. Mamoudzou (Mayotte)

Guissamulo AT, Cockcroft VG (1997) Dolphin and dugong occurrence and distribution and fisheries interactions in Maputo and Bazaruto Bays, Mozambique. In: Proceedings of the 49th international whaling commission meeting, Scientific committee annual meeting, UK

Hart KA, Gray T, Stead SM (2013) Consumptive versus nonconsumptive use of sea turtles? Stakeholder perceptions about sustainable use in three communities near Cahuita National Park, Costa Rica. Mar Policy 42:236-244. doi:10. 1016/j.marpol.2013.03.008

Hauck M (2008) Rethinking small-scale fisheries compliance. Mar Policy 32:635-642. doi:10.1016/j.marpol.2007.11. 004

Hawkins JP, Roberts CM (2004) Effects of artisanal fishing on Caribbean coral reefs. Conserv Biol 18:215-226. doi:10. 1111/j.1523-1739.2004.00328.x
Heinrichs S, O’Malley M, Medd H, Hilton P (2011) Manta ray of hope: global threat to manta and mobula rays. Shark Savers, Wild Aid, San Francisco

Heithaus MR, Frid A, Wirsing AJ, Worm B (2008) Predicting ecological consequences of marine top predator declines. Trends Ecol Evol 23:202-210. doi:10.1016/j.tree.2008.01. 003

Herfaut J (2006) Suivi statistique de la pecherie artisanale Mahoraise: effort de pêche, captures et CPUE en 2005. Service des Pêches de la Direction de l'agriculture et de la Forêt

Hoffmann M et al (2010) The impact of conservation on the status of the world's vertebrates. Science 330:1503-1509. doi: $10.1126 /$ science. 1194442

Huang H-W, Liu K-M (2010) Bycatch and discards by Taiwanese large-scale tuna longline fleets in the Indian Ocean. Fish Res 106:261-270. doi:10.1016/j.fishres.2010.08.005

Humber F, Godley BJ, Ramahery V, Broderick AC (2011) Using community members to assess artisanal fisheries: the marine turtle fishery in Madagascar. Anim Conserv 14:175-185. doi:10.1111/j.1469-1795.2010.00413.x

Humber F, Godley BJ, Broderick AC (2014) So excellent a fishe: a global overview of legal marine turtle fisheries. Divers Distrib 20:579-590. doi:10.1111/ddi.12183

Igulu MM, El Kharousy ZM (2015) Tanzania national report to the scientific committee of the Indian Ocean Tuna Commission, 2015. Tanzania Fisheries Research Institute and Tanzania Deep Sea Fishing Authority

IOTC (2016a) Indian Ocean Tuna commission database. http:// iotc.org/oqs. Accessed 5 Sept 2016

IOTC (2016b) Status of development and implementation of national plans of action for seabirds and sharks, and implementation of the FAO guidelines to reduce marine turtle mortality in fishing operations. IOTC-2016SC19-06[E] Rev_2

IUCN (2016) The IUCN red list of threatened species. Version 2015-4. www.iucnredlist.org. Accessed 09 Mar 2016

IWC (1980) Chairman's report of the thirty-first annual meeting. Rep Int Whal Comm 30:25-41

Jiddawi NS, Shehe MA (1999) The status of shark fishery in Zanzibar, East Africa: a case study. In: Jiddawi NS, Stanley RD (eds) Fisheries stock assessment in the Traditional Fishery Sector: the information needs. Proceedings of the national workshop on the artisanal fisheries sector, Zanzibar. Tanzania Institute of Marine Sciences, University of Dar es Salaam, Zanzibar, Tanzania, pp 87-92

Kasuya T (2007) Japanese whaling and other cetacean fisheries (10 pp). Environ Sci Pollut Res 14:39-48. doi:10.1065/ espr2006.09.346

Keane A, Jones JPG, Edwards-Jones G, Milner-Gulland EJ (2008) The sleeping policeman: understanding issues of enforcement and compliance in conservation. Anim Conserv 11:75-82. doi:10.1111/j.1469-1795.2008.00170.x

Kimani EN, Wambiji N, Aura C, Munga C, Okemwa G (2015) State of the Kenya marine fisheries report 2015. Kenya Marine and Fisheries Research Institute, Mombasa

Kiszka J (2012) Bycatch assessment of vulnerable megafauna in coastal artisanal fisheries in the Southwest Indian Ocean vol South West Indian Ocean Fisheries Project (SWIOFP) 
Kiszka J (2015) 8. Marine mammals: a review of status, distribution and interaction with fisheries in the Southwest Indian Ocean. In: Van der Elst R, Everett B (eds) Offshore fisheries of the southwest Indian Ocean, vol Special Publication 10. Oceanographic Research Institute, Durban, pp 303-324

Kiszka J, van der Elst R (2015) 11. Elasmobranchs (Sharks and Rays): a review of status, distribution and interaction with fisheries of the Southwest Indian Ocean. In: Van der Elst R, Everett B (eds) Offshore fisheries of the southwest Indian Ocean, vol special publication 10. Oceanographic Research Institute, Durban, pp 365-390

Kiszka J, Muir C, Jamon A (2007) Status of a marginal dugong (Dugong dugon) population in the lagoon of Mayotte (Mozambique Channel), in the Western Indian Ocean. West Indian Ocean J Mar Sci 6:111-116

Kiszka J et al (2009) Marine mammal bycatch in the Southwest Indian Ocean: review and need for a comprehensive status assessment. West Indian Ocean J Mar Sci 7:119-136

Kiszka J, Bein A, Bach P, Jamon A, Layssac K, Labart S, Wickel $\mathrm{J}$ (2010) Catch and bycatch in the pelagic longline fishery around Mayotte (NE Mozambique Channel), July 2009September 2010. IOTC WPEB-19

Kiszka JJ, Heithaus MR, Wirsing AJ (2015) Behavioural drivers of the ecological roles and importance of marine mammals. Mar Ecol Prog Ser 523:267-281. doi:10.3354/meps 11180

KMALF (2008) Kenya fisheries annual statistical bulletin 2007. Ministry of Agriculture, Livestock and Fisheries-State Department of Fisheries

KMALF (2014a) Kenya fisheries annual statistical bulletin 2013. Ministry of Agriculture, Livestock and FisheriesState Department of Fisheries

KMALF (2014b) Kenya marine artisanal fisheries frame survey 2014 report. Ministry of Agriculture, Livestock and Fisheries-State Department of Fisheries

KMALF (2015) Kenya fisheries annual statistics report, 2014. Ministry of Livestock and Fisheries Development-Fisheries Statistics Section

Kooiman J, Bavinck M, Jentoft S, Pullin R (2005) Fish for life: interactive governance for fisheries. MARE publication series, vol 3. Amsterdam University Press, Amsterdam

Kyne PM, Simpfendorfer C (2007) A collation and summarization of available data on deepwater chondrichthyans: biodiversity, life history and fisheries. IUCN SSC Shark Specialist Group: 137

Le Manach F, Gough C, Humber F, Harper S, Zeller D (2011) Reconstruction of total marine fisheries catches for Madagascar (1950-2008). In: Harper S, Zeller D (eds) Fisheries catch reconstructions: Islands, Part II. Fisheries Centre research reports, vol 19(4). Fisheries Centre, University of British Columbia

Le Manach F, Bach P, Barret L, Guyomard D, Fleury P-G, Sabarros PS, Pauly D (2015) Reconstruction of the domestic and distantwater fisheries catch of La Réunion (France), 1950-2010. In: Le Manach F, Pauly D (eds) Fisheries catch reconstructions in the Western Indian Ocean, 1950-2010, vol 23(2). Fisheries Centre, University of British Columbia, Vancouver, pp 83-98

Lemahieu A, Blaison A, Crochelet E, Bertrand G, Pennober G, Soria M (2017) Human-shark interactions: the case study of Reunion island in the south-west Indian Ocean. Ocean
Coast Manag 136:73-82. doi:10.1016/j.ocecoaman.2016. 11.020

Lewison RL, Crowder LB, Read AJ, Freeman SA (2004) Understanding impacts of fisheries bycatch on marine megafauna. Trends Ecol Evol 19:598-604. doi:10.1016/j. tree.2004.09.004

Maoulida K, Hauzer M, Poonian C, Kiszka J (2009) Artisanal shark fisheries of the Comoros: status and threats. Paper presented at the 6th scientific symposium of the Western Indian Ocean Marine Science Association, La Réunion, France

Marshall NT (1997a) The Seychelles shark fishery. In: Marshall NT, Barnett R (eds) The trade in sharks and shark products in the Western Indian and Southeast Atlantic Oceans. TRAFFIC, East/Southern Africa, Nairobi, pp 15-18

Marshall NT (1997b) Trade in sharks and shark products in Kenyan waters. In: Marshall NT, Barnett R (eds) The trade in sharks and shark products in the Western Indian and Southeast Atlantic Oceans. TRAFFIC, East/Southern Africa, Nairobi, pp 33-38

Marshall AD, Dudgeon CL, Bennett MB (2011) Size and structure of a photographically identified population of manta rays Manta alfredi in southern Mozambique. Mar Biol 158:1111-1124. doi:10.1007/s00227-011-1634-6

Maunder MN, Punt AE (2004) Standardizing catch and effort data: a review of recent approaches. Fish Res 70:141-159. doi:10.1016/j.fishres.2004.08.002

McVean AR, Walker RCJ, Fanning E (2006) The traditional shark fisheries of southwest Madagascar: a study in the Toliara region. Fish Res 82:280-289. doi:10.1016/j.fishres. 2006.06.016

Meyler SV, Felix H, Crouthers R (2012) Abundance and distribution of Indo-Pacific humpback dolphins (Sousa chinensis) in the Shimoni Archipelago, Kenya. West Indian Ocean J Mar Sci 10:201-209

MFR (2004) Mauritius annual report 2003. Ministry of Fisheries and Rodrigues

MFR (2010) Mauritius annual report 2010. Ministry of Fisheries and Rodrigues-Fisheries Division

MFR (2012) Mauritius annual report 2011. Ministry of Fisheries and Rodrigues

Molina J, Cooke S (2012) Trends in shark bycatch research: current status and research needs. Rev Fish Biol Fish 22:719-737. doi:10.1007/s11160-012-9269-3

Moore JE et al (2010) An interview-based approach to assess marine mammal and sea turtle captures in artisanal fisheries. Biol Conserv 143:795-805. doi:10.1016/j.biocon. 2009.12.023

Mora C et al (2009) Management effectiveness of the world's marine fisheries. PLoS Biol 7:e1000131. doi:10.1371/ journal.pbio.1000131

Muir C (2005) The status of marine turtles in the United Republic of Tanzania, East Africa. Sea sense (Tanzania Turtle \& Dugong Conservation Programme)

Muir CE, Kiszka JJ (2012) Eastern African dugongs. In: Hines EM, Reynolds JE III, Aragones LV, Mignucci-Giannoni AA, Marmontel M (eds) Sirenian conservation: issues and strategies in developing countries. University Press of Florida, Gainesville, pp 84-90

Muir C, Ngatunga B (2007) Rapid gillnet bycatch surveyUnited Republic Of Tanzania. Sea Sense and Tanzania Fisheries Research Institute report 
Musick JA (2005) 14. Shark utilization. In: Management techniques for elasmobranch fisheries, vol FAO Fisheries technical paper No. 474. FAO, Rome, pp 223-226

Ndegwa S (2015) Kenya national report to the scientific committee of the Indian Ocean Tuna Commission, 2015. Ministry of Agriculture Livestock and Fisheries-State Department of Fisheries

Nevill J, Robinson J, Giroux F, Isidore MS (2007) Seychelles national plan of action for the conservation and management of sharks. Seychelles Fishing Authority, Victoria

O'Connor S, Campbell R, Cortez H, Knowles T (2009) Whale watching worldwide: tourism numbers, expenditures and expanding economic benefits, a special report from the International Fund for Animal Welfare. Yarmouth MA, USA, prepared by Economists at Large, p 228

O'Malley MP, Lee-Brooks K, Medd HB (2013) The global economic impact of manta ray watching tourism. PLoS ONE 8:e65051. doi:10.1371/journal.pone.0065051

Obura D (2017) Reviving the Western Indian Ocean economy: actions for a sustainable future. World Wide Fund for Nature (Formerly World Wildlife Fund), Gland, Switzerland

Okemwa GM, Nzuki S, Mueni EM (2004) The status and conservation of sea turtles in Kenya. Mar Turt Newsl 105:1-6

Pauly D (2006) Major trends in small-scale marine fisheries, with emphasis on developing countries, and some implications for the social sciences. Marit Stud 4:7-22

Pauly D, Zeller D (2015) Sea around us concepts, design and data (seaaroundus.org)

Pérez-Jorge S et al (2015) Can static habitat protection encompass critical areas for highly mobile marine top predators? Insights from Coastal East Africa. PLoS ONE 10:e0133265. doi:10.1371/journal.pone.0133265

Pérez-Jorge S, Gomes I, Hayes K, Corti G, Louzao M, Genovart M, Oro D (2016) Effects of nature-based tourism and environmental drivers on the demography of a small dolphin population. Biol Conserv 197:200-208. doi:10.1016/ j.biocon.2016.03.006

Peterson AM, Stead SM (2011) Rule breaking and livelihood options in marine protected areas. Environ Conserv 38:342-352. doi:10.1017/S0376892911000178

Pierce SJ, Trerup M, Williams C, Tilley A, Marshall AD, Raba N (2008) Shark fishing in Mozambique: a preliminary assessment of artisanal fisheries. Eyes on the Horizon, Maputo

Pinnegar JK, Engelhard GH (2008) The 'shifting baseline' phenomenon: a global perspective. Rev Fish Biol Fish 18:1-16. doi:10.1007/s11160-007-9058-6

Poisson F, Taquet M (2001) L'espadon: de la recherche à l'exploitation durable - Programme palangre réunionnais rapport final, Novembre 2001

Poonian CNS (2015) A first assessment of elasmobranch catch in Mauritian artisanal fisheries using interview surveys. Phelsuma 23:19-29

Poonian CNS et al (2008) Rapid assessment of sea turtle and marine mammal bycatch in the Union of the Comoros. West Indian Ocean J Mar Sci 7:207-215

Preen A (1995) Impacts of dugong foraging on seagrass habitats-observational and experimental-evidence for cultivation grazing. Mar Ecol Prog Ser 124:201-213. doi:10. 3354/meps 124201
Pusineri C, Quillard M (2008) Bycatch of protected megafauna in the artisanal coastal fishery of Mayotte Island, Mozambique Channel. West Indian Ocean J Mar Sci 7:195-206

Pusineri C, Kiszka J, Quillard M, Caceres S (2013) The endangered status of dugongs Dugong dugon around Mayotte (East Africa, Mozambique Channel) assessed through interview surveys. Afr J Mar Sci 35:111-116. doi:10.2989/1814232X.2013.783234

Pusineri C, Barbraud C, Kiszka J, Caceres S, Mougnot J, Daudin G, Ridoux V (2014) Capture-mark-recapture modelling suggests an endangered status for the Mayotte Island (eastern Africa) population of Indo-Pacific bottlenose dolphins. Endanger Species Res 23:23-33. doi:10.3354/esr00555

Nielsen JR, Mathiesen C (2003) Important factors influencing rule compliance in fisheries lessons from Denmark. Mar Policy 27:409-416. doi:10.1016/S0308-597X(03)00024-1

Rakotonirina B, Cooke A (1994) Sea turtles of Madagascartheir status, exploitation and conservation. Oryx 28:51-61. doi:10.1017/S0030605300028295

Randriamiarisoa, Rafomanana G (2005) Analyse de l'état de lieux de la pêche traditionnelle aux requins à Madagascar. In: Etat de lieux et proposition de Plan de Gestion de la filière Pêcherie à requins à Madagascar. WWF Project MG0861- Shark Conservation Project. WWF Madagascar/ BCPA. pp 163-208

Razafindrakoto Y, Andrianarivelo N, Rosenbaum HC (2004) Sightings, catches, and other records of Indo-Pacific humpback dolphins in the coastal waters of Madagascar. Aquat Mamm 30:103-110. doi:10.1578/am.30.1.2004.103

Razafindrakoto Y, Andrianarivelo N, Cerchio S, Rasoamananto I, Rosenbaum H (2008) Preliminary assessment of cetacean incidental mortality in artisanal fisheries in Anakao, southwestern region of Madagascar. West Indian Ocean J Mar Sci 7:175-184. doi:10.4314/wiojms.v7i2.48275

Read AJ, Drinker P, Northridge S (2006) Bycatch of marine mammals in US and global fisheries. Conserv Biol 20:163-169. doi:10.1111/j.1523-1739.2006.00338.x

Remie S, Mortimer JA (2007) First records of olive ridley turtles (Lepidochelys olivacea) in Seychelles. Mar Turt Newsl 117:9-10

Riedmiller S (2013) Dolphin hunting in Pangani worries tourism stakeholders. All Africa. http://allafrica.com/stories/ 201304150052.html. Accessed 23 Aug 2016

Robards MD, Reeves RR (2011) The global extent and character of marine mammal consumption by humans: 1970-2009. Biol Conserv 144:2770-2786. doi:10.1016/j.biocon.2011. 07.034

Robinson L, Sauer WHH (2013) A first description of the artisanal shark fishery in northern Madagascar: implications for management. Afr J Mar Sci 35:9-15. doi:10.2989/ 1814232X.2013.769906

Romanov EV (2002) Bycatch in the tuna purse-seine fisheries of the Western Indian Ocean. Fish Bull 100:90-105

Salas S, Chuenpagdee R, Seijo JC, Charles A (2007) Challenges in the assessment and management of small-scale fisheries in Latin America and the Caribbean. Fish Res 87:5-16. doi:10.1016/j.fishres.2007.06.015

Schaeffer D (2004) Assessment of the artisanal shark fishery and local shark fin trade on Unguja Island, Zanzibar. Independant Study Project (ISP) Collection: 536 
SFA (2001-2013) Seychelles artisanal fisheries statistics 2001-2013 technical reports. Seychelles Fishing Authority

SFA (2015) Fisheries statistical report, year 2014. Seychelles Fishing Authority

Short RE (2011) Identification of pitfalls in development of community management for shark fisheries of Northern Madagascar. Masters Thesis, Imperial College London

Smale MJ (1998) Evaluation of shark populations around the Masoala Peninsular, North East Madagascar. Wildlife Conservation Society, Madagascar Country Programme, Antananarivo

Smale MJ (2008) Pelagic shark fisheries in the Indian Ocean. In: Camhi MD, Pikitch EK, Babcock EA (eds) Sharks of the open ocean: biology, fisheries and conservation, vol 15 . Wiley-Blackwell, Hoboken, pp 247-259. doi:10.1002/ 9781444302516.ch21

Soilihi AS (2014) Union des Comores rapport national destiné au Comité scientifique de la Commission des thons de l'océan Indien, 2014. Direction Générale des Ressources Halieutiques

Soondron S, Duhurmeea Z, Sooklall T (2013) Mauritius national report to the scientific committee of the Indian Ocean Tuna commission, 2013. Ministry of Fisheries, Mauritius

Sousa MI, Marshall NT, Smale MJ (1997) The shark trade in Mozambique. In: Marshall NT, Barnett R (eds) The trade in sharks and shark products in the Western Indian and Southeast Atlantic Oceans. TRAFFIC, East/Southern Africa, Nairobi, pp 67-79

Sparre P, Venema SC (1998) Introduction to tropical fish stock assessment-part 1: manual. FAO, Rome

Stead SM, Troell M, Edwards P (2015) International peer review report of the Seychelles Mariculture Master Plan Planning Process. The Seychelles Fishing Authority, Victoria

Stensland E, Carlen I, Sarnblad A, Bignert A, Berggren P (2006) Population size, distribution, and behavior of indo-pacific bottlenose (Tursiops aduncus) and humpback (Sousa chinensis) dolphins off the south coast of Zanzibar. Mar Mam Sci 22:667-682. doi:10.1111/j.1748-7692.2006.00051.x

Teh LCL, Sumaila UR (2013) Contribution of marine fisheries to worldwide employment. Fish Fish 14:77-88. doi:10. 1111/j.1467-2979.2011.00450.x

Tittensor DP, Mora C, Jetz W, Lotze HK, Ricard D, Berghe EV, Worm B (2010) Global patterns and predictors of marine biodiversity across taxa. Nature 466:1098-1101. doi:10. 1038/nature09329

TMLFD (2015) Tanzania fisheries annual statistics report2014. Ministry of Livestock and Fisheries DevelopmentFisheries Development Division

UN (2015) United Nations Department of Economic and Social Affairs Population Division, world population prospects: the 2015 revision, volume I: comprehensive tables (ST/ ESA/SER.A/379)

UN (2016) Chronological lists of ratifications of, accessions and successions to the convention and the related agreements. http://www.un.org/Depts/los/reference_files/chronological_ lists_of_ratifications.htm\#Agreement $\% 20$ for\%20the $\% 20$ implementation $\% 20$ of $\% 20$ the $\% 20$ provisions $\% 20$ of $\% 20$ the $\% 20$ Convention $\% 20$ relating $\% 20$ to $\% 20$ the $\% 20$ conservation $\%$ 20 and $\% 20$ management $\% 20$ of $\% 20$ straddling $\% 20$ fish $\%$ 20stocks $\% 20$ and $\% 20$ highly $\% 20$ migratory $\% 20$ fish $\% 20$ stocksAccessed 9 Nov 2016

UNEP (2010) Amended convention of the protection, management and development of the marine and coastal environment of the Western Indian Ocean. UNEP, Nairobi

van der Geest C (2017) Redesigning Indian Ocean fisheries governance for 21 st century sustainability. Glob Policy 8:227-236. doi:10.1111/1758-5899.12447

Vannuccini S (1999) Shark utilization, marketing, and trade. vol FAO fisheries technical paper No. 389. FAO, Rome

VLIZ (2014) Union of the ESRI Country shapefile and the exclusive economic zones (version 2). http://www. marineregions.org/. Accessed 1 Dec 2016

Wallace BP et al (2010) Global patterns of marine turtle bycatch. Conserv Lett 3:131-142. doi:10.1111/j.1755263X.2010.00105.x

Wallace BP et al (2011) Global conservation priorities for marine turtles. PLoS ONE 6:e24510. doi:10.1371/journal. pone. 0024510

Wallace BP, Kot CY, DiMatteo AD, Lee T, Crowder LB, Lewison RL (2013) Impacts of fisheries bycatch on marine turtle populations worldwide: toward conservation and research priorities. Ecosphere 4:1-49. doi:10.1890/ES1200388.1

Wanyonyi IN, Wamukota A, Mesaki S, Guissamulo AT, Ochiewo J (2016) Artisanal fisher migration patterns in coastal East Africa. Ocean Coast Manag 119:93-108. doi:10.1016/j.ocecoaman.2015.09.006

Ward P, Lawrence E, Darbyshire R, Hindmarsh S (2008) Largescale experiment shows that nylon leaders reduce shark bycatch and benefit pelagic longline fishers. Fish Res 90:100-108. doi:10.1016/j.fishres.2007.09.034

WB (2012) The hidden harvests: the global contribution of capture fisheries, vol 66469-GLB. World Bank, Washington, DC

WB (2016a) Fishing Communities in the Comoros Develop Fishing Management Projects. World Bank. http://www. worldbank.org/en/news/feature/2016/06/14/fishing-comm unities-in-the-comoros-develop-fishing-management-proj ects?cid=EXT_WBSocialShare_EXT. Accessed 7th November 2016

WB (2016b) Population projection tables by country and group. World Bank. http://www.worldbank.org/. Accessed 17 Sept 2013

Webster I, Cockcroft VG, Cadinouche A (2014) Abundance of the Indo-Pacific bottlenose dolphin Tursiops aduncus off south-west Mauritius. Afr J Mar Sci 36:293-301. doi:10. 2989/1814232X.2014.946448

Weigmann S (2016) Annotated checklist of the living sharks, batoids and chimaeras (Chondrichthyes) of the world, with a focus on biogeographical diversity. J Fish Biol 88:837-1037. doi:10.1111/jfb. 12874

Wekesa PN (2013) Kenya national report to the scientific committee of the Indian Ocean Tuna Commission, 2013. Ministry of Agriculture Livestock and Fisheries-State Department of Fisheries

Wekesa PN (2014) Kenya national report to the scientific committee of the Indian Ocean Tuna Commission, 2014. Ministry of Agriculture Livestock and Fisheries-State Department of Fisheries 
Whitcraft S, Hofford A, Hilton P, O’Malley M, Jaiteh V, Knights P (2014) Evidence of declines in shark fin demand, China. WildAid, San Francisco

WIOMSA (2011) Migrant fishers and fishing in the Western Indian Ocean: socio-economic dynamics and implications for management. Final Report of Commissioned Research Project MASMA/CR/2008/02

Worm B, Branch TA (2012) The future of fish. Trends Ecol Evol 27:594-599. doi:10.1016/j.tree.2012.07.005

Worm B et al (2013) Global catches, exploitation rates, and rebuilding options for sharks. Mar Policy 40:194-204. doi:10.1016/j.marpol.2012.12.034
WWF-EAME (2004) Towards a Western Indian Ocean dugong conservation strategy: the status of dugongs in the Western Indian Ocean region and priority conservation actions. World Wide Fund, Dar es Salaam

ZMLF (2010) Zanzibar fisheries frame survey report 2010. Ministry of Livestock and Fisheries-Department of Fisheries Development

Žydelis R, Wallace BP, Gilman EL, Werner TB (2009) Conservation of marine megafauna through minimization of fisheries bycatch. Conserv Biol 23:608-616. doi:10.1111/j. 1523-1739.2009.01172.x 